\title{
واقع استخدام الشبكة العنكبوتية في تدريس مواد الدراسات الإسلامية بالمرحلتين المتوسطة والثانوية
}

\section{نايف بن عوضن بن نامي الشلاحي الططيرe}

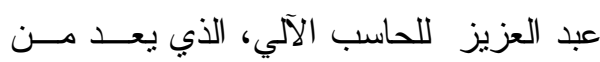

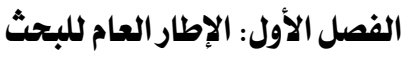

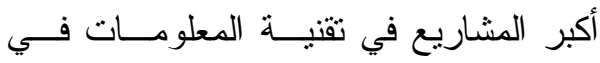

المجال التزبوي في المملكة ، وله أهداف من لهن

إن التزبية والتعليم من أهم الركــائز

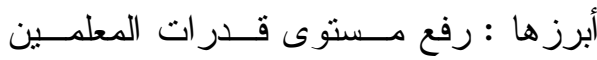

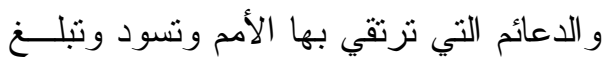

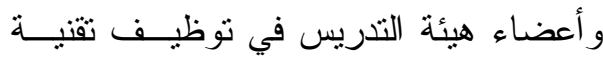
من المجد ذروته و لا يمكن لأي امة بحال من المن وتئي

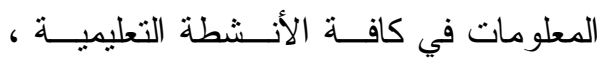

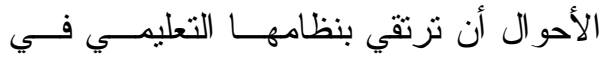

وإيجاد البيئة المعلوماتية الملائمة لاحتياجات مختلف المجالات حتى تسخر جميع طاقاتهــا

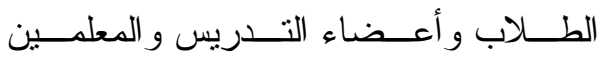
وكو ادرها البشرية لنظوير نظامها التزبــوي

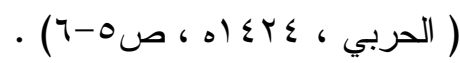

و لا شك أن الاهتمام بتقنية المعلومات

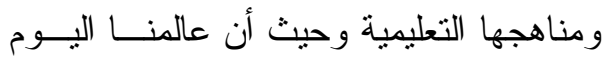

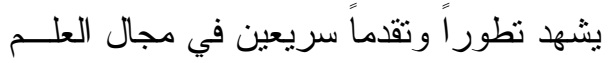
له آثاره الإيجابية في جميع مجالات الحياة ،

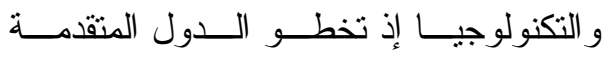

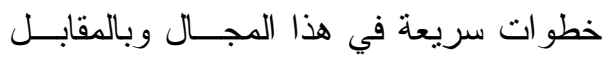

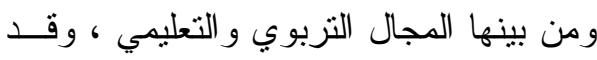

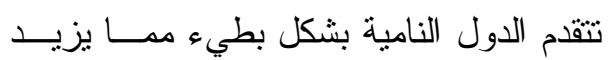
الفجوة العلمية التكنولوجية بينهم وبين الدول

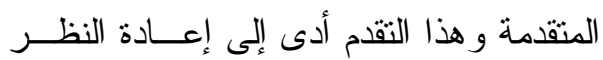
بالتعليم ومناهج الدراسة في الحقول المختلفة

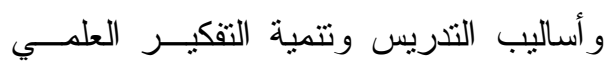

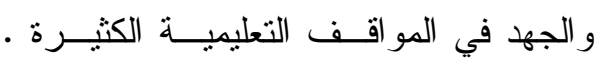

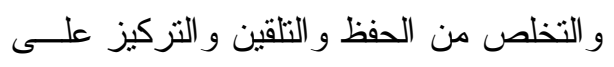

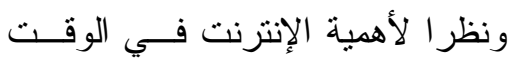

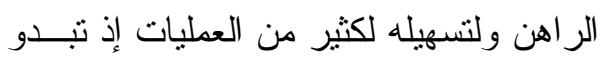
التقكير الناقد و استخدام التقنيات التعليمية في وني

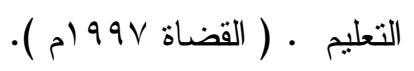

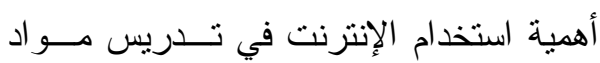

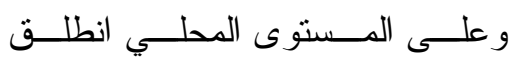

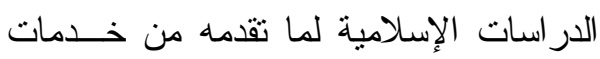
مشروع " وطني " مشروع الملك عبد الله بن 
مشكلة البحث

و لا شـــك أن للار اســـات الإســـلامية

فروع مختلفة تتطلب من معلميها الرجـوع الإسئ

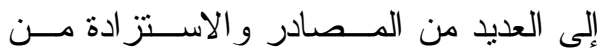
المعلومات و القدرة على الاتصـال بــالطلاب بأسر ع وقت و أقل جهد ممكن و هذا ما تحققه الإنترنت عن طريق التواصل الثقني بمختلق

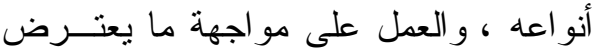
ذللك من معوقات تمنع أو تقلل من الاســتفادة

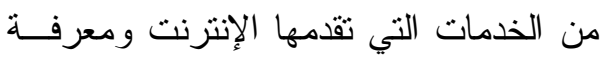
مجالات استخدام الإنترنت في التدريس كمــا

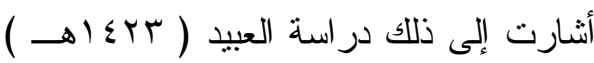

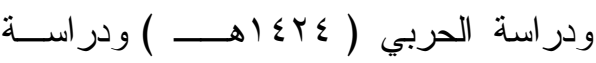

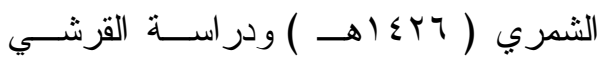

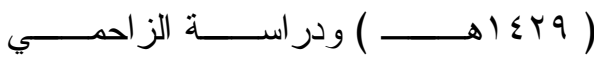

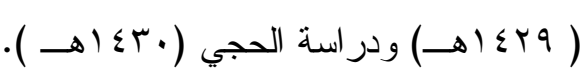
لهذا سعت وزارة التربيــة و التعلـــم بالمملكة العربية السعودية إلى إنشاء مر اكــز مصادر للتعلم في أغلب المدارس و إدخــال خدمة الانترنت بها من اجل نطوير المهار ات المتعددة للطلاب وتقديم نسهيلات تعليمية في أماكن الدراسة لرفع مستوى التحصيل العلمي

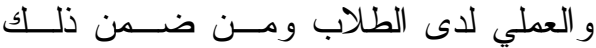
مدارس محافظة عفيف. وبحكم عمل الباحــث فــي الميـــان التربوي لمس أهية الانترنت و الاستفادة منه

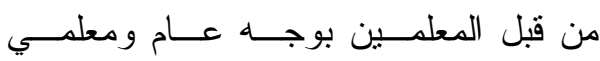

تناهم في توسيع نطاق التعلم ونسمح للطالب

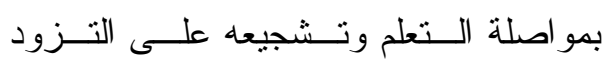

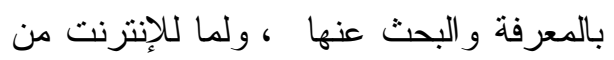
دور في تحسين وتظوير التنريس في العملية

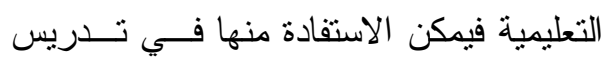

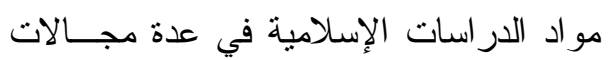

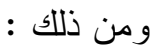
ففي مجــال القــران الكــريم يـــوفر الإنترنت فرصة الاستماع إلى قر اءة نموذجية و إعادة سماعها لأكثر من مرة دون ملل . لإلترل وفي مجال التفسير إمكانية الرجوع إلـى ديى

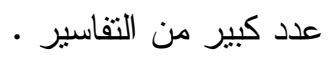
وفي مجال الحديث توجد أمهــات كتـبـب الحديث مع شروحها . مجيا

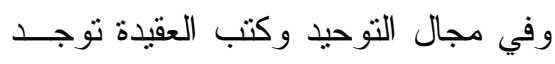

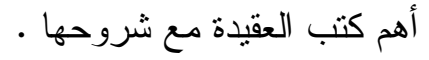
وفي مجال الفقه توجد أمهات الكتب فـي

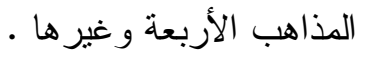
و هنالك العديد من المجلات و الــدوريات السنوية و الثشرية التي بستفاد منها في العلوم

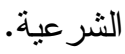
ومن خلال هذا البحث سـنتعرف علىى و اقع استخدام الثبكة العنكبوتية في تــدريس مـــو اد الدر اســات الإســلامية بــالمرحلتين المتوسطة و الثانوية بمحافظة عفيف . 


$$
\begin{aligned}
& \text { لاستخدام الإنترنت من قبل معلمـي }
\end{aligned}
$$

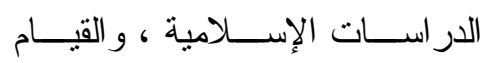

$$
\begin{aligned}
& \text { بمعالجة جوانــب القـصور - إن } \\
& \text { وجدت - من أجل نوظيــف هــــه } \\
& \text { الثقنية بأكبر قدر ممكن في العملية } \\
& \text { التعليمية لاسيما في هذا العصر . } \\
& \text { r- تسهم في تطوير طرق تدريس مو اد } \\
& \text { الدر اسات الإســـلامية بــالمرحلتين }
\end{aligned}
$$

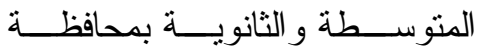

$$
\begin{aligned}
& \text { عفيف. }
\end{aligned}
$$

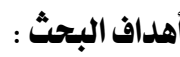

$$
\begin{aligned}
& \text { 1- التعرف على أوجه الاســتفادة مــن } \\
& \text { خدمات الثبكة العنكبوتية في مجال } \\
& \text { تدريس مواد الدراسات الإســلامية } \\
& \text { بالمرحلنين المتوسطة و الثانوية . لكرين } \\
& \text { r- ـ التعرف على الآليات التي يمكـن أن } \\
& \text { تؤدى إلى زيــادة الاســتفادة مــن } \\
& \text { خدمات الثبكة العنكبونية في تدريس }
\end{aligned}
$$

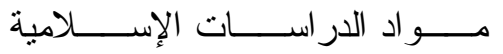

$$
\begin{aligned}
& \text { بالمرحلتين المتوسطة والثانوية . } \\
& \text { r- الوقوف على المعوقات الثخــصية } \\
& \text { و الإدارية و التقنية التي قد تحول دون التون }
\end{aligned}
$$

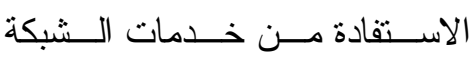

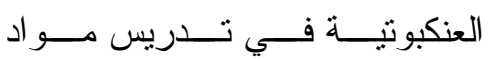

$$
\begin{aligned}
& \text { الدراسات الإســـامية بــــالمرحلتين } \\
& \text { المتوسطة و الثانوية . }
\end{aligned}
$$




\section{مصطلحات البحث}

أسئلة البحث

التدريس باستخدام الثبكة العنكبونية :

السؤال الرئيس للبحث هو :

يعرفه الباحث إجر ائياً بأنه استخدام الـشبكة

ما و اقع استخدام الثبكة العنكبوتية في

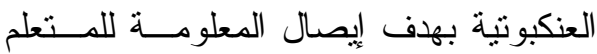

بأقل جهر و أكثر جودة .

تدريس مواد الدراسات الإســـامية :

تــــريس مـــــواد الدراســــات الإســـلامية

بالمرحلتين المتوسطة و الثانوية؟

ويتفرع منه الأسئلة الآتية :

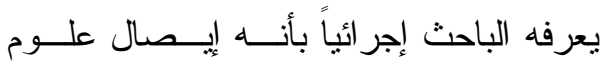

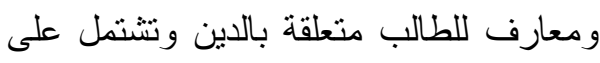

فروع وهي القران الكريم و التفسير و التوحيد

$$
\text { و الحديث و الفقه . }
$$

الفصل الثاني: الإطار النظري والدراسات السابقة

$$
\text { مفهوم الثبكة العنكبوتية : }
$$

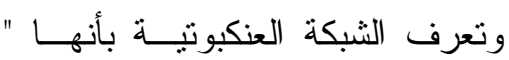

شبكة معلومات عالمية عبارة عن مجموعــة

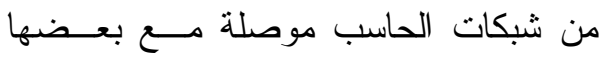

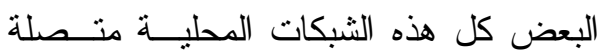

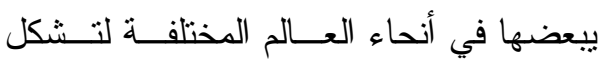

شبكة واحدة ضخمة تتقل المعلومــات مسنـ

منطقة إلى منطقة بسرعة فائقة وبشكل دائـم

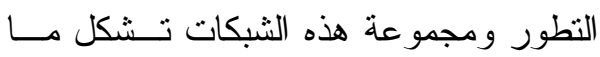

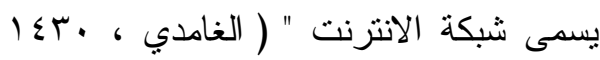

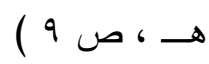

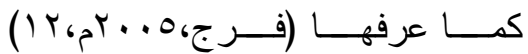

بأنها:"الثبكات الحاسوبية المتو افرة كافة التي يتصل بعضها ببعض لتشكل شبكة و اســعة تتقل المعلومات من منطقة لأخرى بـسر عة

فائقة، وبشكل دائم التطور".

/ / ما أوجه الاستفادة من خدمات الــشبكة

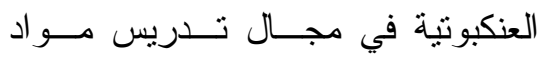

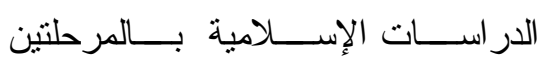

المتوسطة و الثانوية ؟

/ / ما الآليات التي يمكن أن تـؤدى إلــى

زيادة الاستفادة مـن خــدمات الـشبكة

العنكبوتية في تدريس مواد الدراســات

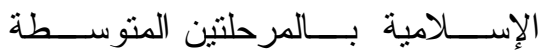

و الثانوية ؟

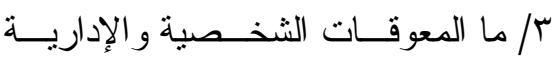

و التقنية التي قد تحول دون الاستفادة من خدمات الثبكة العنكبونية فـي تــدريس مو اد الدر اسات الإســـلامية بــالمرحلتين المتوسطة و الثانوية ؟

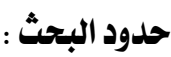

اقتصر البحث على واقــع اســتخدام

الثبكة العنكبونية في تدريس مواد الدراسات الإسلامية بالمرحلتين المتوسطة و الثانويــة بمحافظة عفيف . 
وفي الـسبعينات نـشأت مؤســسة

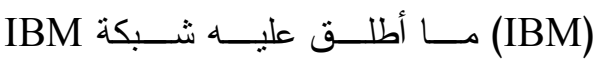
و الثمانينيات تـــم تكـــوين الــشبكة العالميــة للانترنت عن طريــق المؤسـسـة الوطنيــة الأمريكية التي تولت إثثهار و انتشار استعمال الانترنت في التسعينات، وفي الألفية الثالتـــة

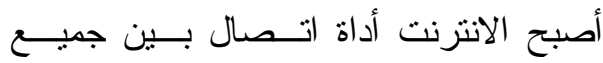
القار ات، و أصبح يعتمد عليه فــي التجــارة

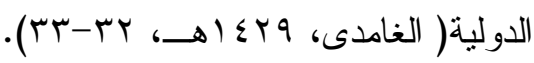

\section{بداية الثبكة العنكبوتية فـــي المملكــة}

العربية السعودية:

بدأ إدخال الانترنـــت فـي المملكـــة

العربية السعودية فور صدور قرار مجلـس السبس

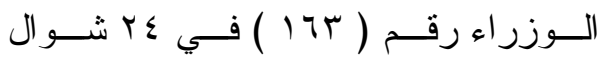

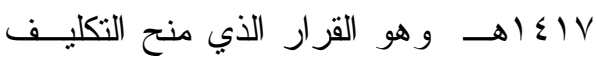

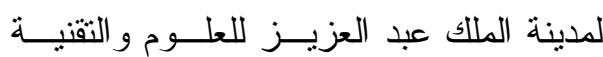
بمهمة إدخال خدمة الإنترنت، وقامت المدينة

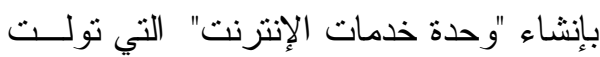
اتخاذ كافة الإجــر اءات اللازمسـة لإدخــال

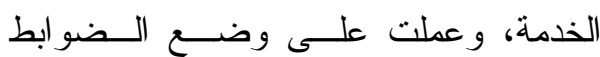

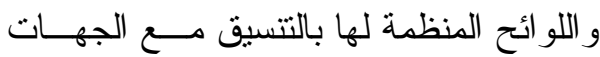

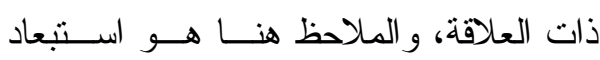

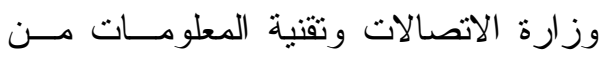
عملية إدخال خدمة الإنترنت إلى البلاد رغم

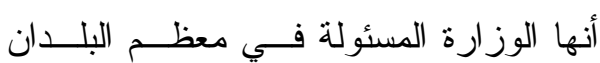

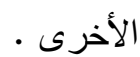

مراحل تطور الثبكة العنكبوتيه:

بدأت الأصول الأولى لشبكة الانترنت منذ ظهور الحرب الباردة بين المعسكرين

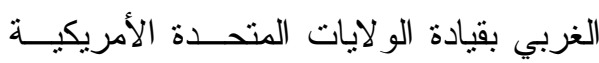
و الشرقي بقيادة الاتحاد السوفيتي سابقاً. وقد تطور بناء شبكة الانترنت بعــــ

غزو روسيا للفضاء وبـــــ سـبـاق التـسلح

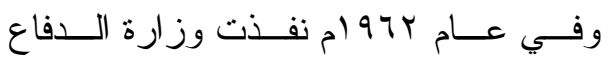

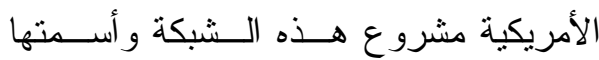
Advanced Research Agency Arpanet إجر اء أبحاثهم لإنشاء شبكة كمبيوتز عملاقة كان الهدف من تأسيسها في ذلك الوقت خدمة

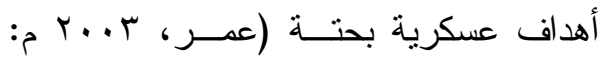
ص (ז) وفي عام |9V| م تطورت شــبكة أربانت حتى وصلت إلى عشرين موقع مــن

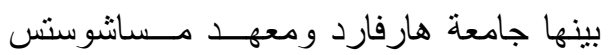

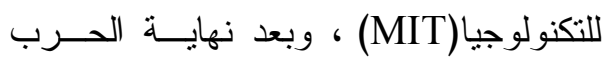
الباردة بين الو لايات المتحدة وروسيا بــــأت وبعات

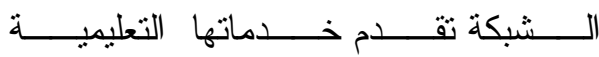
و الأكاديمية،وفي عام 9 ام تم تو توصيل

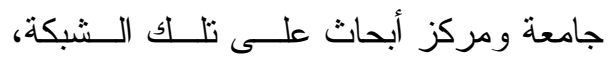

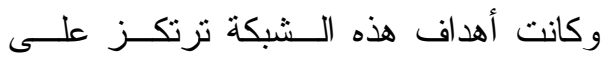
إمكانية تبادل المعلومات كالأبحاث فيما بــين

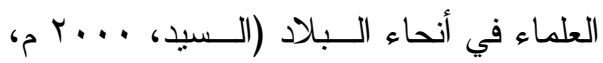
(19). (19) 
المعلومات النصية و المقــرو عة و المـسمو عة

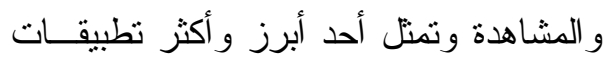
الإنترنت استخداماً وشيو عاً.

r. المنتديات ومجموعات النقاش : التي يتم من خلالها التحاور و التتاقش

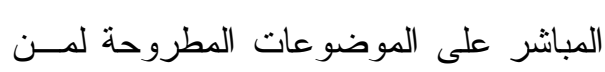

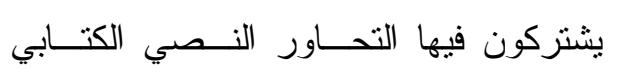

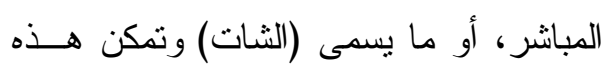
الخدمات من المحاورة المباثرة عبر تبــادل العبار ات النصية كتابة بشكل حي ومباثــر

$$
\begin{aligned}
& \text { ( التميمى، • ( • r م، ع). } \\
& \text { ع. ـ القوائم البريدية }
\end{aligned}
$$

القائمة البريدية فأنها تـسمح بتبــادل الرسائل الإلكترونية بين مجموعة كبيرة من المشتركين في القائمة لمناقشة موضو علين معين

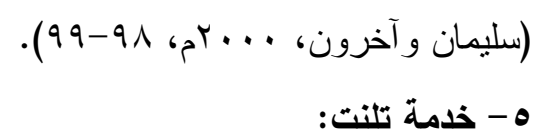

وتعد هذه الخدمة من أقــدم خــدمات

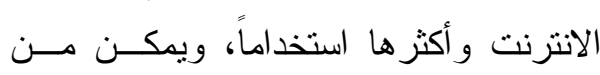
خلال هذه الخدمة قر اءة مقالات أو كت بـب أو الون

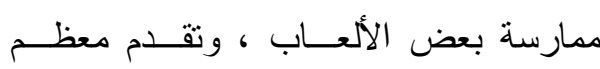

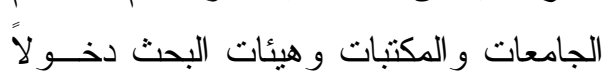

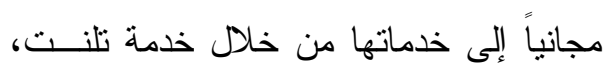

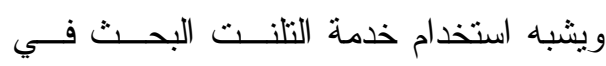

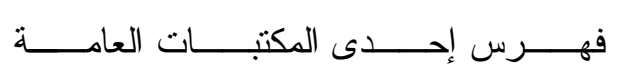

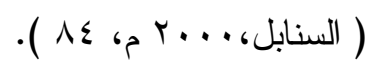

وفعليا بدأت خدمة الانترنت حيث تــم

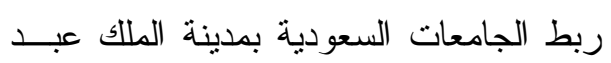

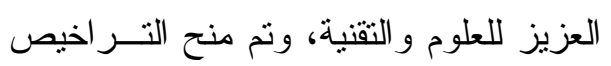

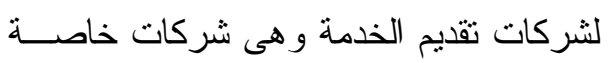
حصلت على التراخيص من مدينة الملك عبد العزيز للعلوم و التقنية وفق الثروط و اللوائح، من مدينه

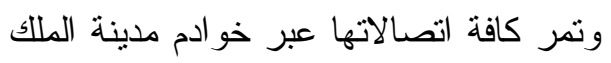
عبد العزيز للعلوم و الثقنية . أنواع الخدمات الموجــودة علــى الــشبكة

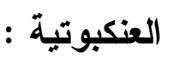

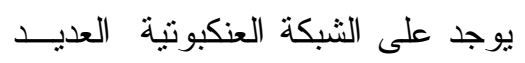
من الخدمات التي ز ادت من أهميتها ، خاصة

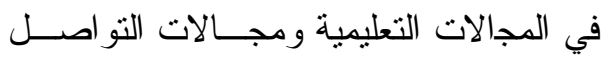
الاجتماعي، ومن أبرزها: ا. البريد الاككتروني : ويعد البريد الإلكتروني وسيلة ناجحة جداً لإرسال واستقبال الرسائل البريدية على ولى الإكئي نائي

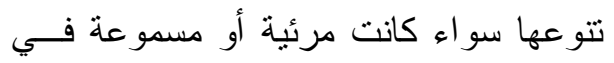

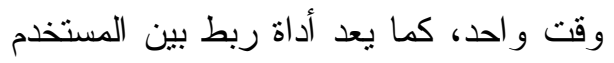

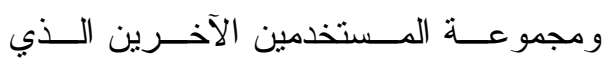
يجمعهم اهتمام مشترك لتبــادل المعلومــات

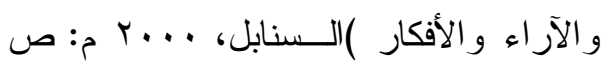

\section{r. مواقع الإنترنت:}

وتسمى اصطلاحاً الـششبكة النسـيجية و التي يمكن للمستخدم من خلالهــا تـصفح اصنص 
إمكانية مشاركة الملفات و الــصور وتبـــادل مقاطع الفيديو، وكذللك مكنت مستخدميها من

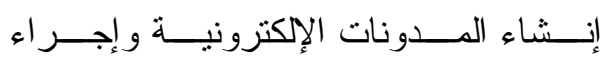

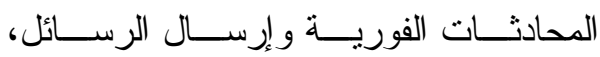
وتصدرت الشبكات الاجتماعية هـــــثناتـــة مو اقع هامة ورئيسية هي: الفيس بوك وتونير وموقع مقاطع الفيديو اليوتيوب.

عناصر الثبكة العنكبوتية:

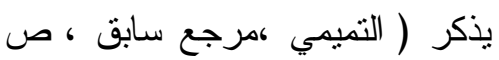

0-7 ) أن الشبكة العنكبوتية تحتوي بـشكل

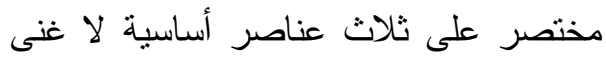

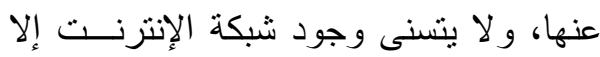
بوجودها وهذه العناصر هي :

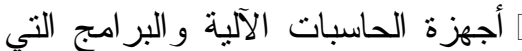

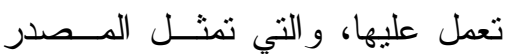

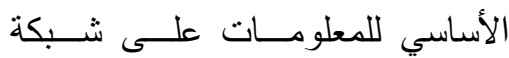
الإنترنت. $\square$ الأشخاص الذين يقضون أوقاتهم على

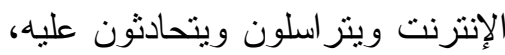

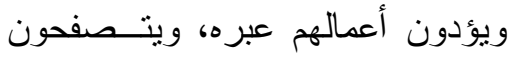
الإنترنت.

口 أجززة الثبكات وملحقاتها وتنشمل كل الإنل

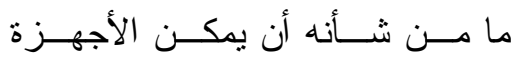
و المستخدمين من الثو اصل وتــشمل أموراً من قبيل المحو لات و المقسمات

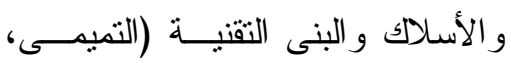
.

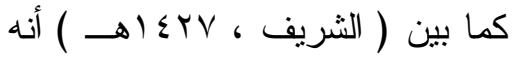

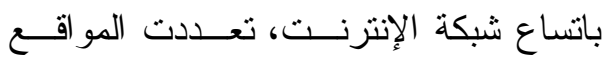
الإلكترونية التي تقوم بمهمات عديــدة وفقــاً للغرض من إنشائها، سواء أكانت مؤسساتية أو شخصبة، وهي بتعددها هذا تقدم الكثبـــــ من الخدمات المتتوعة، وتصنف هذه المواقع إلى أنماط متعددة هي : "المو اقع المعلوماتية:

تضم هذه المواقع من حيث المحتــوى

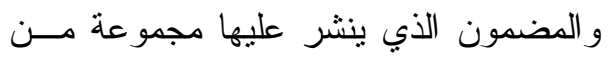

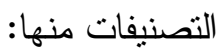
أ- - المواقع التعريفية. ب- ب- المواقـع

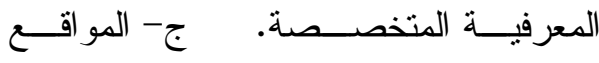
الإخبارية.

$$
\text { د- المنتديات. هـ - المو اقع الخدمية. }
$$

يقتصر عمل هذه المواقع على تقــديم

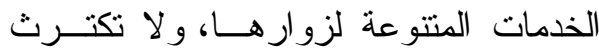

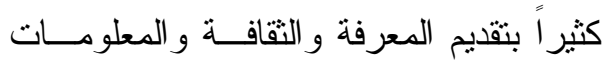

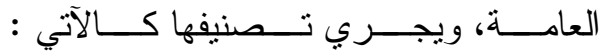

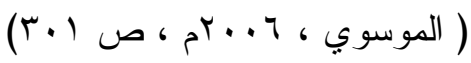

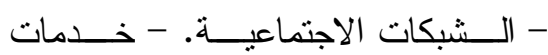

المــشاركة. - الخــــمات البرمجيــــة. - الخدمات السريعة - المواقع الاجتماعية : ولقد بــين ( الجمــال ، 999 ام ) أن هذه المو اقع الاجتماعية أتاحت لمت صفحيها 
وأصبحت طريقــة الحـصول علــى

المعلومات من خلال الثبكة العنكبوتية مسـن

أسهل الطرق لاعنمادها على طريقة الرسوم

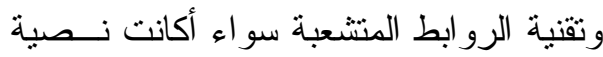

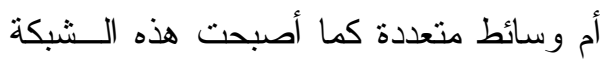

أكثر التطبيقات الثعبية على الإنترنت .

إن مــن أهـــم اســتخدامات الـششبكة

العنكبوتية إمكانية كل شخص تصميم صفحة

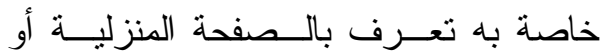

الصفحة الخاصة ويمكن إنشاء صفحة خاصة كما تريد وتتظمها وقد تــضع بهـــا بعـض

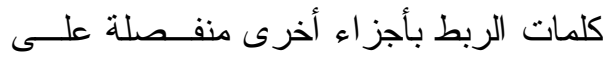
الإنترنت ( التودري ، ع . . بم). أسس تكنولوجيا التعليم :

ويقوم التعليم القــائم علــى اســـتخدام

التكنولوجيا على مجموعة من الأسس تتمنل

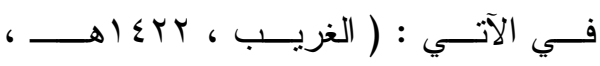

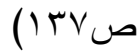

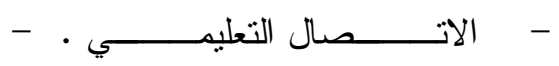

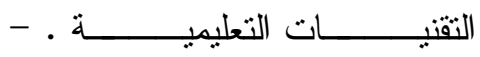

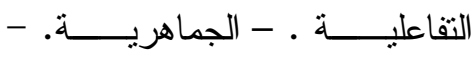

اللاتز امنية في المكان و الزمان. -

تكنولوجيا التعليم.

ولقد أجريت فـي الـسنوات العـشر

الأخيرة العديد من الدر اســات فــي مجــــال

استخدام الحاسب في التعليم وإن اختلف في
فو ائد الشبكة العنكبوتية:

إن مجالات الاســفادة مــن الـشبكة

العنكبوتية عديدة ومتتعبة، وتختلف الاستفادة

الفردية للمتطلبات الخاصة لــدى المـستخدم

للإنترنت بينما الاســتفادة الجماعيــة ينظـــر

فبيها للنفع العام، ومن المجالات المنتوعة لهن

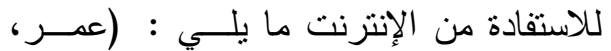

$\left(r q_{6} r^{2}+r\right.$

( ـتشيط التبادل التجاري.

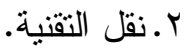

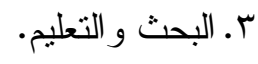

ع.نشر الثقافة الإسلامية عالمياً.

خدمــة المعلومــات مــن خــلال الــشبكة

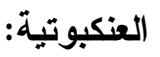

وتمنل الشبكة العنكبوتية مركزًا رئيسًا

للمعلومات المنتشرة عالميًا ولوثائق مت مصلة

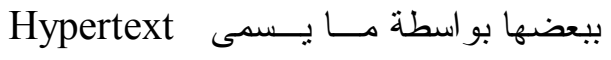

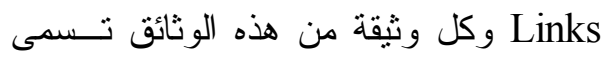
صفحة Home Page وتحتوى هذه الصفحة على خاصية الربط Hypertext بعدد مسن

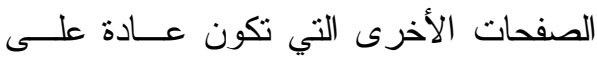

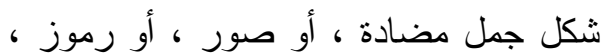

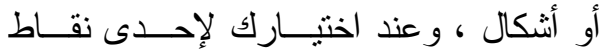
الربط Links فإنها نقوم على نقل الــصفحة

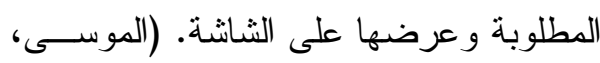

.$(r . .0$ 


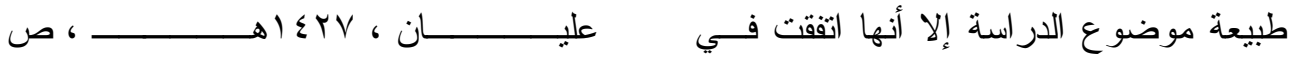

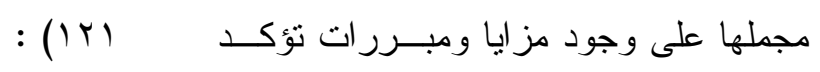

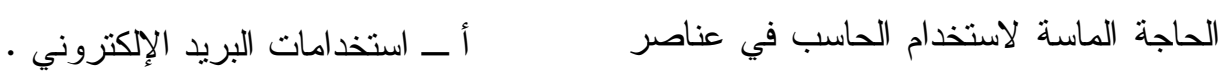

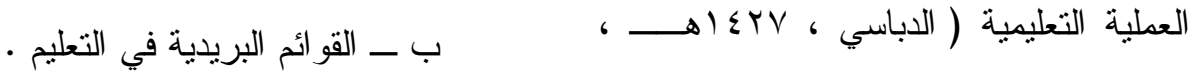

$$
\begin{aligned}
& \text { ج - استخدام نظام مجموعات الأخبــار } \\
& \text { في التعليم التحلم } \\
& \text { د ـ ـ استخدامات بر امج المحادثـة فـــي } \\
& \text { • التعليم التيح } \\
& \text { هـ - استخدام الإنترنـــت و الإنتر انــت } \\
& \text { و الإكستر انت. } \\
& \text { r- استخدام الكتاب الإكتروني. } \\
& \text { مز ايـــا وعيــوب اســـتخدام الـــشبكة } \\
& \text { العنكبوتية في التعليم : } \\
& \text { أولا : المزايا : } \\
& \text { من مزايا استخدام الثبكة العنكبونية في }
\end{aligned}
$$

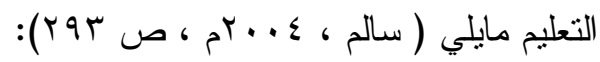

$$
\begin{aligned}
& \text { 1- خلق بيئة تعليمية تعلمية تفاعلية مسن }
\end{aligned}
$$

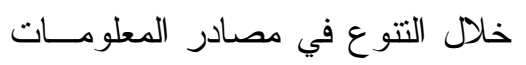

$$
\begin{aligned}
& \text { و الخبرة. } \\
& \text { ص (19). (19.) } \\
& \text { مجالات توظيف الـشبكة العنكبوتيــة فـــي } \\
& \text { التعليم : } \\
& \text { تعتبر شبكة الإنترنت الأكثر انتـشاراً }
\end{aligned}
$$

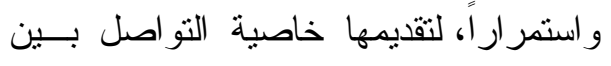

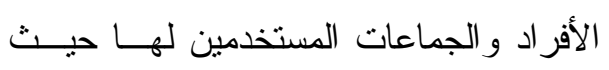

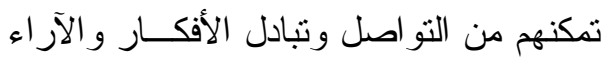

$$
\begin{aligned}
& \text { و المعلومات و الملفات و الصور و أفلام الفيديو }
\end{aligned}
$$

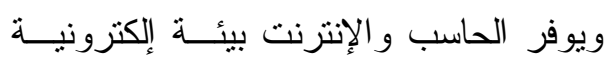

$$
\begin{aligned}
& \text { فائمة على التفاعل وتساهم بشكل كبير فـي وني } \\
& \text { عملية التعليم و التعلم ويقتر ح (العبــــالكريم) }
\end{aligned}
$$

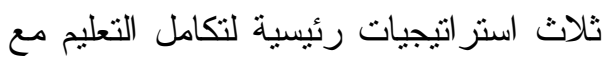

$$
\begin{aligned}
& \text { مظاهر تكنولوجيا المعلومات، وهي ( العبـــ }
\end{aligned}
$$

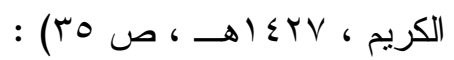

$$
\begin{aligned}
& \text { 1- استخدام الحاسوب داخل الفصل: } \\
& \text { r- استخدام الإنترنت في التعليم : } \\
& \text { r- تعزيز العلاقة بــين أوليـاء الأمــور } \\
& \text { و المدرسة و البيئة الخارجية. } \\
& \text { يمكن استخدام الإنترنت للقبام بأعمال }
\end{aligned}
$$

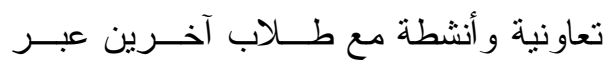

$$
\begin{aligned}
& \text { ب- دعم عملية التفاعـلـل بــين الطــلاب } \\
& \text { الإنترنت كما يمكن استخدامه لتحميل البر امج } \\
& \text { و المعلمين من خلص تبادل الخبــرات }
\end{aligned}
$$

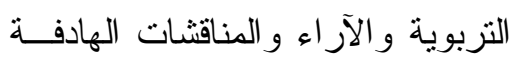

$$
\begin{aligned}
& \text { الدراسية وخطط الدروس. وتقدم الإنترنـــت }
\end{aligned}
$$

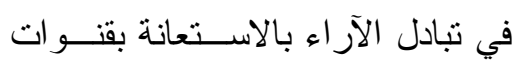

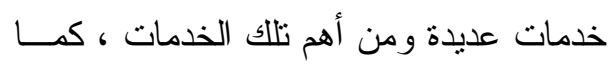

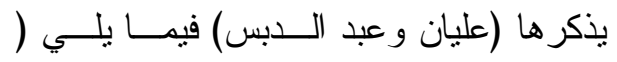




$$
\begin{aligned}
& \text { بالإنترنت قد تفوق إمكانيات بعـض } \\
& \text { الطلاب محدودي الاخل. } \\
& \text { ينطلب تدريب للمعلمــين و الطــلاب }
\end{aligned}
$$

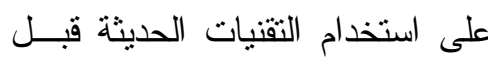

$$
\begin{aligned}
& \text { بداية تتفيذ التعليم عبر الشبكات. }
\end{aligned}
$$

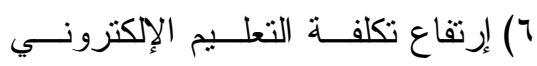$$
\text { وخاصة في المر احل الأولية لتطبيقه }
$$

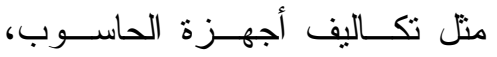$$
\text { تكاليف تصميم البرمجيات ونطوير ها }
$$$$
\text { وتحديثها، تكاليف خطوط الاتصالات }
$$$$
\text { و الصيانة المستمرة ورسوم الاتصال }
$$$$
\text { بالإنترنت. }
$$$$
\text { يفتقر التعليم عبــر الــشبكات إلـــى (V) }
$$$$
\text { التو اجد الإنساني والعلاقات الإنسانية }
$$$$
\text { بين المعلم و الطـــلاب ، و والطــلاب }
$$$$
\text { بعضهم البعض بتو اجدهم في مكــان }
$$$$
\text { واحد. }
$$

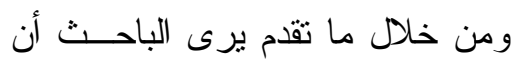

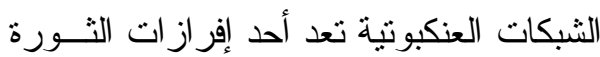
التكنولوجية وتوظيف مستحدثات العصر في عملية التعليم والتعلم يعد أمر ضروريا حيث لعبت شبكات التو اصــل الاجتمـــاعي أدواراً عديدة، أهمها النو احي التعليميــة و الــــياسية

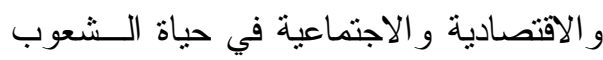

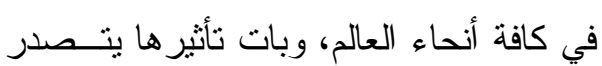
أحداث الساعة نظراً لارنباط قطاع كبير من أن

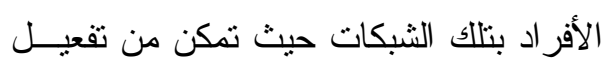

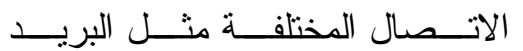

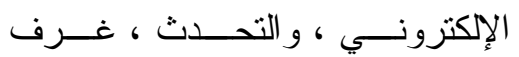

$$
\text { الصف الافتر اضية. }
$$

ـ - اكتساب المعلمين المهـــارات التقنيــة

لاستخدام التقنيات التعليمية الحديثة.

0- إكساب الطلاب المهار ات أو الكفايات

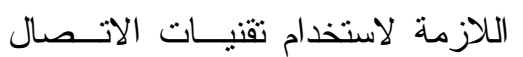

$$
\text { و المعلومات. }
$$

ثانيا : عيوب الثبكة العنكبوتية في التعليم :

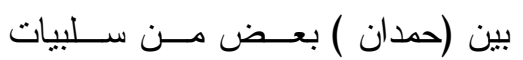

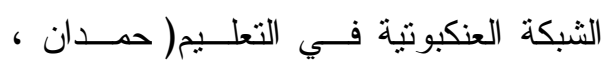
: YOT صن (O)

(1) قد يكون التركيز الأكبر على الجانب (ه) (1)

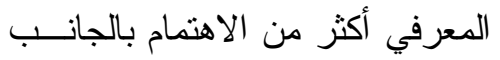

$$
\text { المهاري و الجانب الوجداني. }
$$

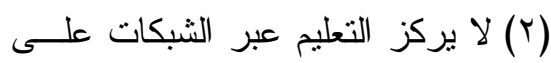

كل الحو اس بل على حاستي الـسمع على على و البصر فقط دون بقية الحواس.

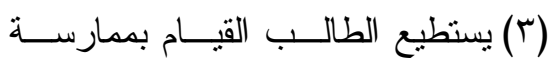

نشاطات اجتماعية وثقافية ورياضية في التعليم النظامي ولكـن يــصعب ممارسة منل تلك النـشاطات فـي ولني

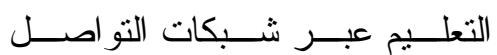

$$
\text { الاجتماعي. }
$$

(§) يحتاج نطبيق التعليم عبر الــشبكات

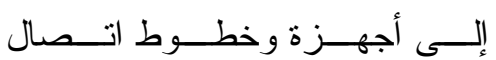


و المعرفة و النشاطات التــي علـى

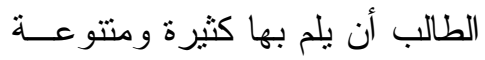
و الفترة الزمنية المخصصة لتعلمها في الوقت ذاته قليلة مما جعل دور المعلم في عصر الإنترنت مخططا

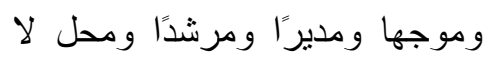

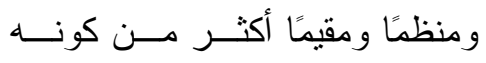
شارحًا للمعلومات مختبر ا للطلاب. ( دروزه ،999) r - إتاحة الفرص للطالب للمشاركة في

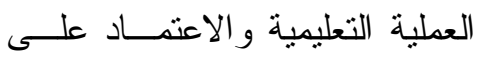

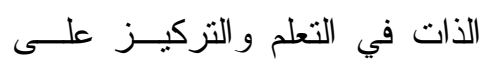

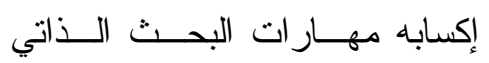

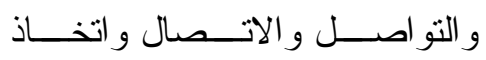
القرارات التربوية المتعلقة بتعلمــهـ وذللك لإجراء التخريج للرواد فــي مادة الحديث عن طريق البحث في كتب الحديث من الانترنت. ץ- دمج الطالــب بنـشـاطات تربويـــة منهجية ولا منهجية متتوعة تــؤدي لـوني إلى بلورة مو اهبه وتقجــر طاقاتــهـ وتتمية قدر اته مما يؤدي إلى تكامل شخصيته ككل كإتاحسة الفرصــة للطالبة حول البحث عن شخصيات إسلامية و التعرف على منجــز اتهم

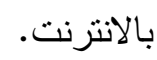

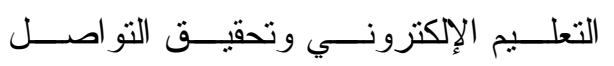
الاجتماعي و التعامل مع المعلومة و الخبـــر

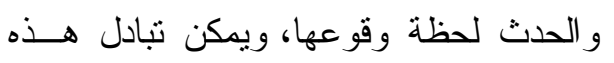

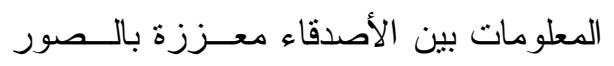

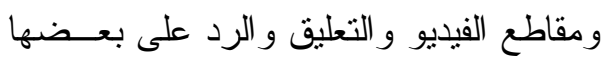

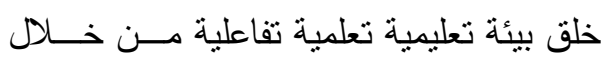

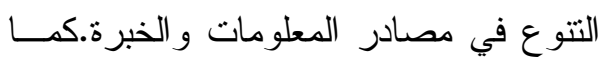

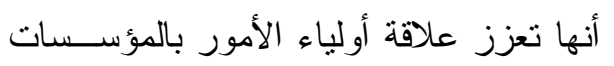

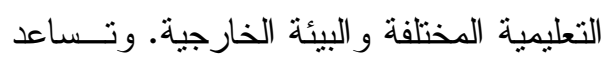

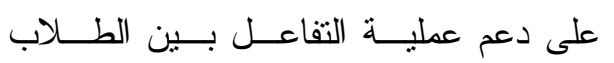
و المعلمين من خلال تبادل الخبرات التربوية

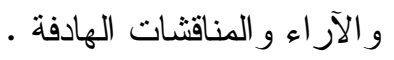

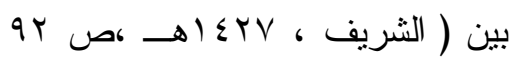
) بأن هنالك سلبيات للشبكة العنكبوتية تتمنل في الآتي : بان هن

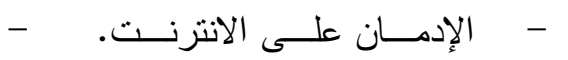

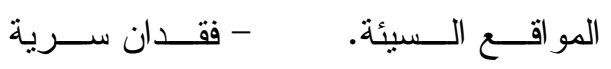
المعلومات: دور الإتترنت في تحسين تـــريس العلــوم

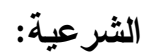
للإنتزنت دور كبيـر فـي تحسـين

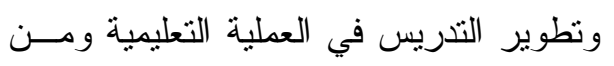
هذه الأدوار ما يلي:

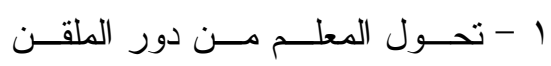

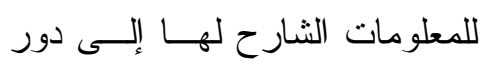

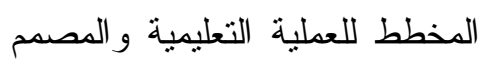

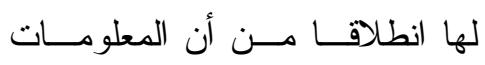


ا.مواقع الإنترنت: تشمل خدمات نشر

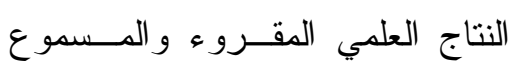

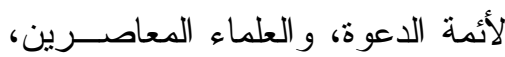

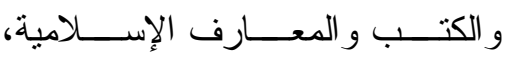

و الفتاوى و الأسئلة، و الدعوة و التعريف

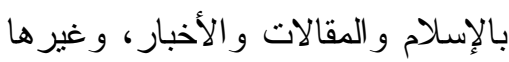

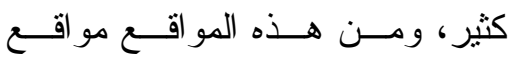

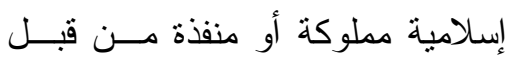

أفر اد قائمين عليها ومو اقع منفدة مــن مئن

قبل جهـات ومؤسـسـات خيريــة أو

رسمية، و هي سهلة ومتاحة للجميــع،

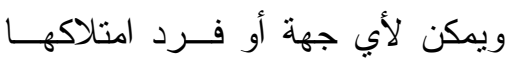

ونشر المقالات و المعلومات عليهــا.

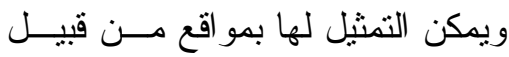

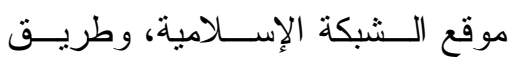

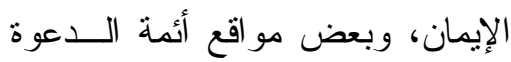

كموقع سماحة الثيخ ابن باز ، و الثيخ

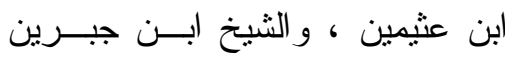

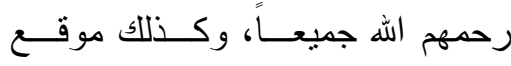

الإسلام اليوم، و غير ها كثثر .

r.بر امج البث المبانشر أو المسجل عبــر

الإنترنت :وهي عبارة عن بر امج بــتم

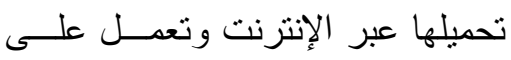

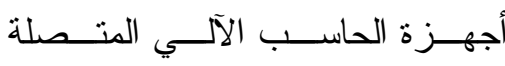

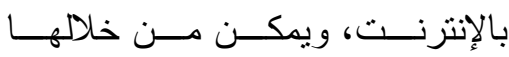

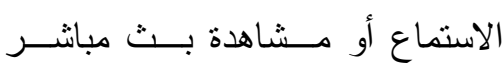

للاروس الثرعية التي يتم إلقاءها في
ع - التعــرف علــي الوســائل التقنيـــة

و الاتصالات وكيفية استخدامها فــي لـوسي التعلم و التعليم.

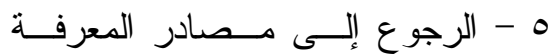

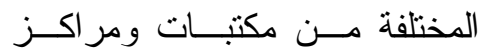

تعليمية ووسائل إعـلام ومواقــع

إسلامية، كموقع رسالة الإســلام،

وصيد الفو ائد وغير ها، لاســتخر اج

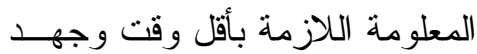

وتكلفة.

1

على الإنتــاج و الإبــــاع، مـــؤهلا

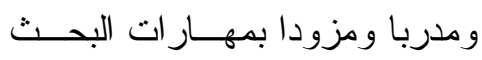

الــذاتي، قـــادر ا علـــى اســـتخدام

الحاسوب وشبكة الإنترنت العالمية،

ذا شخصية قوية منسجمة جسميا

وعقليا و اجتماعيا ووجدانيا وثتقفيا،

وقادر ا على مواجهة أعباء الحيــاة

ومجابهة التحديات و الوقوف أمسـام

تحديات العصر بكل ثقة .

فوائد الثبكة العنكبوتية في تدريس العلــوم الشرعية :

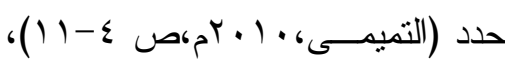

بعض الفو ائد للشبكة العنكبوتية في تــدريس العلوم الثرعية على النحو التالي: 


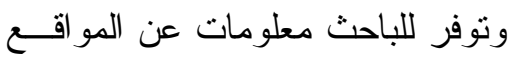

التي تحتوي على المعلومات المناسبة

لما يبحث عنه، و هي كثيرة جداً منها

دليل الــردادي، والخيمـــة العربيـــة فئة

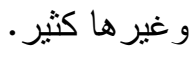

مجالات تطبيق الـشبكة العنكبوتيــة فــي

$$
\text { تدريس العلوم الثرعية : }
$$

تتيح إمكانات الثبكة العنكبونية إجر اء

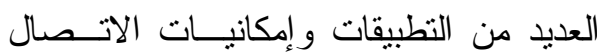

و التحاور المباشرة ونبادل المعلومات و البحث

و غير ها، ولكن يمكن إجمال أبرز النطبيقات

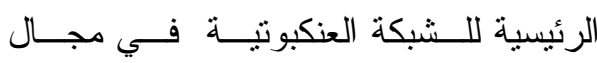

الدراسات الاسلامية في الأمور التالية:

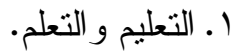

r. الدعوة و الأمر بالدعروف و النهي عن

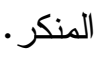

r. الفتاوى و اجابة السائلين.

ع ـ نشر المــصنفات و الكتــب العلميــة

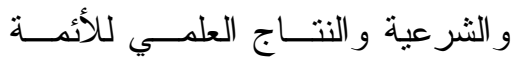

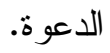

هـ التو اصل و التشاور بين العلماء وطلبة

$$
\text { العلم: }
$$

أهمية استخدام الـشبكة العنكبوتيــة فــي

تدريس مواد الار اسات الإسلامية :

وتتمثل أهمية استخدام الانترنت في الآتـي :

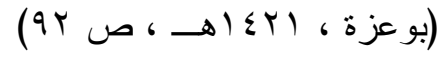

الــدورات العلميــة، أو المـسـاجد أو

حلقات التعليم الثرعي، ومن أنثهرها

برنامج البالتوك و الذي يوفر إمكانيـــة

الدخول إلى عشرات الغرف الإسلامية

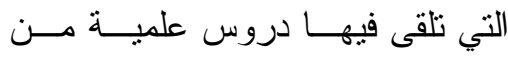

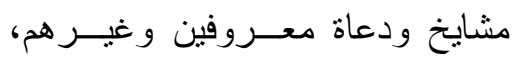

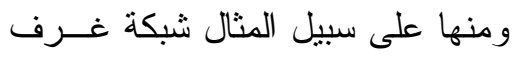

موقع حامل المسك، و التي تتيح النقل

المباشر للاروس و الدور ات الـشر عية ولثية

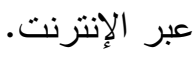

r.مو اقع المكتبات وقو اعــــ البيانـــات:

و التي تتيح إمكانية الدخول من قبـلـل

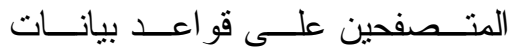

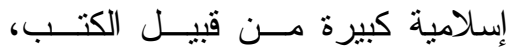

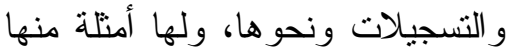

موقع مكتبة المدينة الرقميــة وموقــع

$$
\text { الور اق و غير ها. }
$$

ـ. المنتديات ومو اقع المحاورة المباشرة:

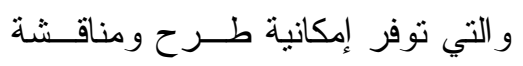

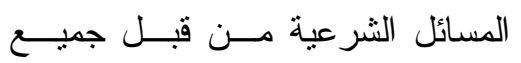

المشتركين في تلكــم المنتــديات، أو فئ

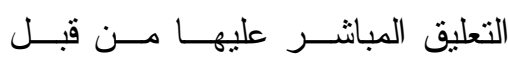

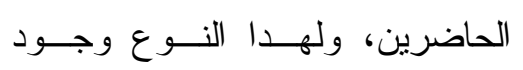

$$
\text { وانتشار كبير على الإنترنت. }
$$

ه.مواقع الأدلة الإسلامية: وهي عبارة

عن مواقع توفر معلومات عن المواقع

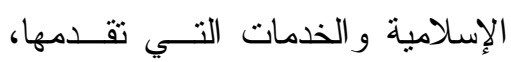




$$
\begin{aligned}
& \text { تفسير القرآن العظــيم لابــن كثيــر }
\end{aligned}
$$

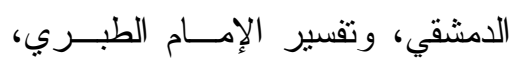

$$
\begin{aligned}
& \text { وتقسير الإمام السعدي، و غير ها. }
\end{aligned}
$$

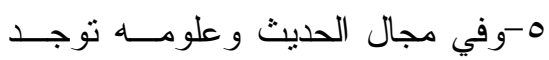

$$
\begin{aligned}
& \text { أمهات كتب الحديث مع شروحها كما } \\
& \text { تتوفر الكتب المهمة في علوم الحديث، }
\end{aligned}
$$

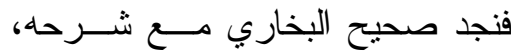

$$
\begin{aligned}
& \text { وصحيح مسلم مع شــرحه، والـسنن }
\end{aligned}
$$

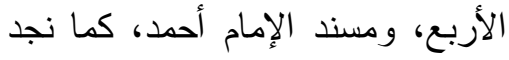

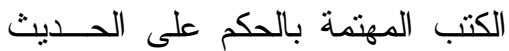

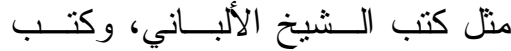

$$
\begin{aligned}
& \text { تخريج الأحاديث منل كتاب (المعجــ } \\
& \text { المفهرس لألفاظ الحـديث النبــوي)، } \\
& \text { و هذه الخدمة قد تساعد المعلــم علـى لـى }
\end{aligned}
$$

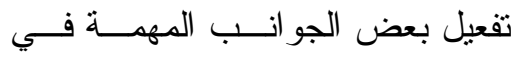

$$
\begin{aligned}
& \text { تدريس الحديث النبــوي، فــثنا إذا لـا }
\end{aligned}
$$

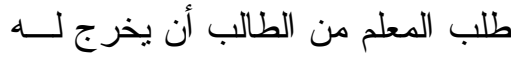

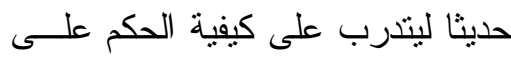

$$
\begin{aligned}
& \text { الحديث، فإنه بحاجة إلى ما يربو على لئى } \\
& \text { خمسين مجلدا ، فقد بصعب عليه ذلك } \\
& \text { لذا في الغالب تكون در اسة هذه المادة }
\end{aligned}
$$

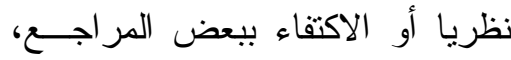

$$
\begin{aligned}
& \text { وهذا خطــأ، ولعـلـل فـــي اســتخدام } \\
& \text { الإنترنت ما يعين على تدريس هــــه وله } \\
& \text { المادة بصورة صحيحة. } \\
& \text { צ-وفــي مجـــال العقيـــدة و المـــذاهب } \\
& \text { المعاصرة نجد أهم كتب العقيدة مــع ولـ }
\end{aligned}
$$

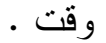




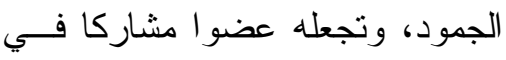

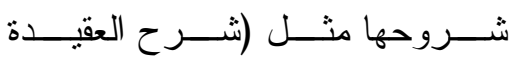

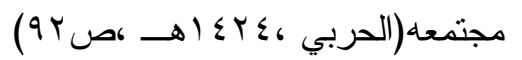

$$
\begin{aligned}
& \text { الطحاوية) لابن أبي العز الدمـشقي، }
\end{aligned}
$$

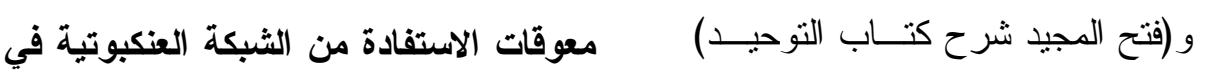

$$
\begin{aligned}
& \text { لعبد الرحمن بن حسن، بالإضافة إلى مجال تدريس مواد الاراسات الإسلامية : } \\
& \text { حيث نوجد مجموعة من المعوقـات } \\
& \text { التي تحول دون الاستفادة من خدمات شــبكة }
\end{aligned}
$$

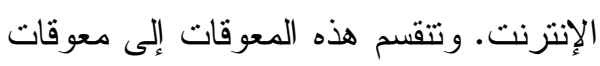

$$
\begin{aligned}
& \text { شخصية، ومعوقات إدارية، ومعوقات ثقنية، } \\
& \text { وذللك على النحو الآتي: }
\end{aligned}
$$

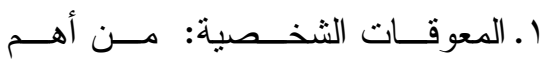

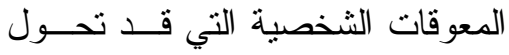

$$
\begin{aligned}
& \text { دون الاستفادة من خـدمات الـشبكة } \\
& \text { العنكبوتية هي التهيب مــن اســتخدام } \\
& \text { الحاسب الآلي و التهيب من اســتخدام } \\
& \text { الإنترنت وعــــم تـــوفر المهـــارات } \\
& \text { اللازمة لاستخدام الأدوات المختلفــة } \\
& \text { للإنترنت و عدم كفاية المعرفة باللغـــة التحنة } \\
& \text { الإنجليزية، و عدم متابعة المسـتجدات } \\
& \text { في مجالي الحاسب الآلي والإنترنت. }
\end{aligned}
$$

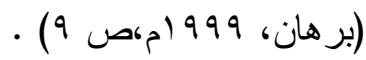

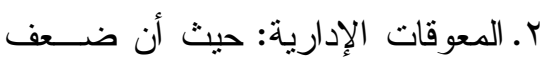

$$
\begin{aligned}
& \text { التــدريب لكــلـ مــن المـستخدمين } \\
& \text { و المتخصصين في مر اكـز الحاســبـ } \\
& \text { بالإدارات الحكومية يعد من المعوقات }
\end{aligned}
$$

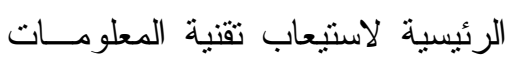

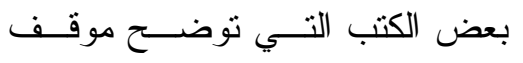

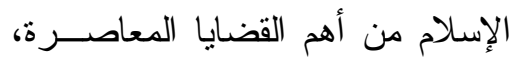

$$
\begin{aligned}
& \text { وخطورتها على الإسلام و أهله وكيفية } \\
& \text { التعامل معهم ، وهذا يقلل من أعبــاء } \\
& \text { المعلم ويوفر له الوقت الذي قد يقضيه } \\
& \text { في زيادة فعالية التدريس، و الاهتمــام }
\end{aligned}
$$

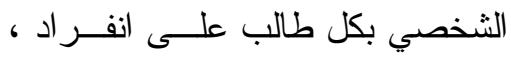

$$
\begin{aligned}
& \text { و القيام بأنشطة إرشادية أخرى أثنــاء } \\
& \text { الدرس. } \\
& \text { V-وفي مجال الفقه وأصوله نجد أمهات } \\
& \text { الكتب في المذاهب الأربعة وغيرهــا، } \\
& \text { بالإضــافة إلــى شــروحها لعلمـــاء }
\end{aligned}
$$

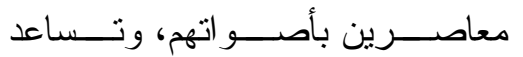

$$
\begin{aligned}
& \text { الإنترنت المعلم و الطالب على متابعة } \\
& \text { الجديد في مجال تخصــصه، وفيمـــا } \\
& \text { يستجد من أحداث ودر اسات من خلا } \\
& \text { متابعته للاوريات الإسلامية المتــوفرة } \\
& \text { عبر الإنتزنت و التي تربو على ثلاثين }
\end{aligned}
$$

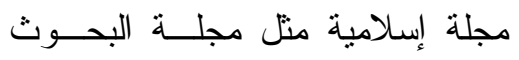

$$
\begin{aligned}
& \text { الفقهية، مجلة الدعوة، مجلة الأســرة، الدهاء } \\
& \text { ومجلة البيان، وكل هذه المجالات تبعد } \\
& \text { عضو هيئة التدريس و الطالــب عــن ولن }
\end{aligned}
$$


في مجال الإنترنت، و التغير ات السريعة فـي

مجال تقنية المعلومات، و عدم وجود مرونــــة الإترنة

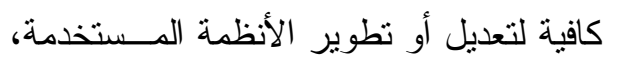
وصعوبة تأمين الحماية الأمنية للمعلومات.

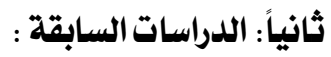

أ- د دراسات تتعلق بمــواد الدراســات

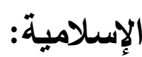

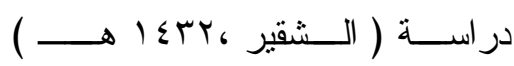

بعنو ان " معوقات استخدام معلمــي العلـــوم

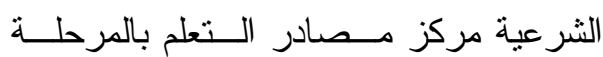

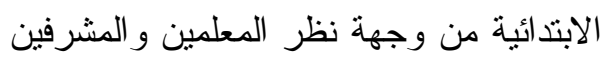

التزبويين " الابنين

هـــف الدر اســـة : الوقــوف علــى

المعوقات التي نواجه معلمي العلوم الثرعية

في استخدام مركز مصادر التعلم بالمرحلـــة

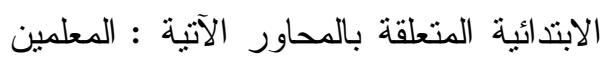

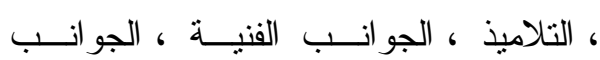

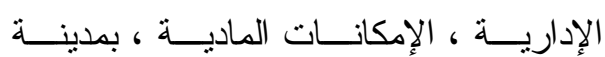

الرياض ، وكذلك تعرّّ الفروق بين إجابات

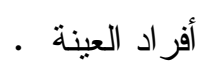

منهج الدراســـة : اســتخدم الباحــث

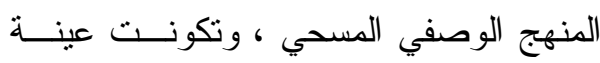

البحث من ( \$ §) مشرفا و (

للعلوم الثرعية ، وكانت الاستبانة هي الأداة

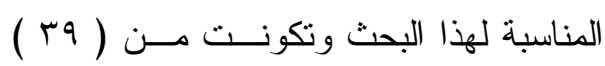

عبارة موز عة على محاور البحث .
في الأجهزة الحكومية (العبد القـادر

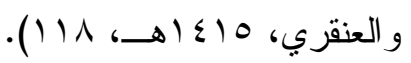

ولذلك فإن أهم المعوقات الإدارية التي

قد تحول دون الاستفادة من خـدمات

الــشبكة العنكبوتيــة تـشـمل الثقافـــة

التنظيمية السائدة، وعدم وجود خطط

إستر اتيجية لتفعيـلـل الاســتفادة مــن وعن

خدمات الإنترنت، وعدم وجود إدارة

متخصصة بتقنية المعلومات، وعـدم

توفير أجززة الحاسب الآلي، وعـلدم

توفير خدمة الإنترنت، وعدم تــوفير

الدورات التدريبية في مجالي الحاسب الحبرسب

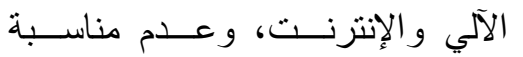

$$
\text { الإجر اءات المعمول بها. }
$$

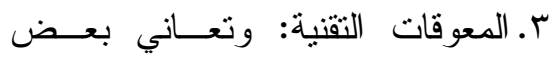

المنظمات من قلة الإمكانيات الماديـــة

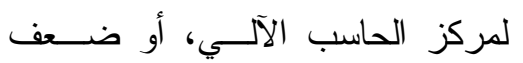

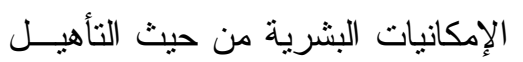

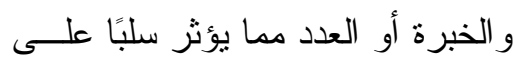

قدرنها في استيعاب تقنيات المعلومات

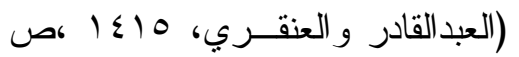

.$(1) 1$

ولذلك فإن أهم المعوقات التقنية التـي

قد تحول دون الاستفادة من خــمات شــبكة

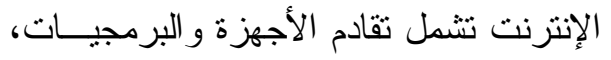

و عدم وجود مو اصفات محددة يجب مر اعاتها

عند شر اء الأجهزة، ونقص الخبر ات التقنيــة 


$$
\begin{aligned}
& \text { المعلومات الدولية الانترنــت فــي تــدريس } \\
& \text { أبرز النتائج : توصل الباحــث إلـى }
\end{aligned}
$$

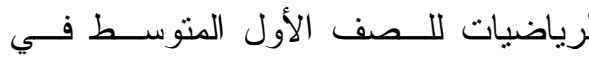

$$
\begin{aligned}
& \text { محافظة الطائف " } \\
& \text { هـــف الدر اســـة : الوقــوف علـىى } \\
& \text { المعوقات التي تتسبب في عزوف المعلمـين } \\
& \text { عن استخدام الحاسوب و الانترنت في تدريس } \\
& \text { وجود عدد من المعوقات تتعلــق باســتخدام } \\
& \text { معلمي العلوم الثرعية مركز مصادر التعلم }
\end{aligned}
$$

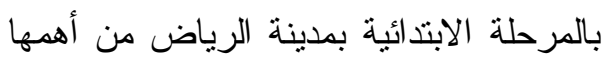

$$
\begin{aligned}
& \text { مايلي : ارتفــاع نــصـاب معلمــي العلــوم } \\
& \text { الثرعية ، قلة الدورات التدريبية التي تتعلق }
\end{aligned}
$$

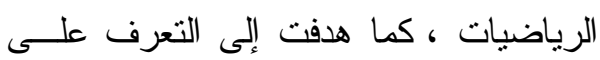

$$
\begin{aligned}
& \text { بكيفية استخدام مـصـادر الـتـعلم ، انـشغال } \\
& \text { وجهات نظر المعلمين في نوع العلاقة بـين }
\end{aligned}
$$

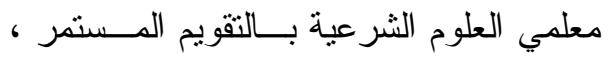

$$
\begin{aligned}
& \text { هذه المعوقات وفاعلية تدريس الرياضــيات }
\end{aligned}
$$

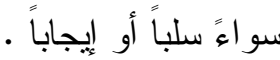

$$
\begin{aligned}
& \text { ضعف مهار ات بعض معلمي العلوم الثرعية }
\end{aligned}
$$

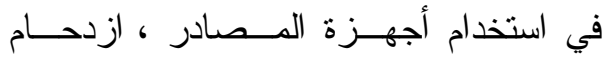

$$
\begin{aligned}
& \text { منهج الدر اسة : اســتخدم الباحــث المــنهج }
\end{aligned}
$$

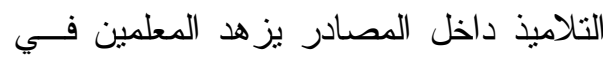

$$
\begin{aligned}
& \text { • التحليلي } \\
& \text { أبرز النتائج : } \\
& \text { / / عدم توفر أجززة العرض . } \\
& \text { r/ عدم توفر المكان المناسب لاســتخدام }
\end{aligned}
$$

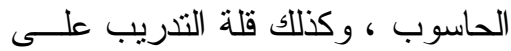

$$
\begin{aligned}
& \text { أوجه استخدامه في التدريس. } \\
& \text { ن } \\
& \text { بالعربية . بوم نو }
\end{aligned}
$$

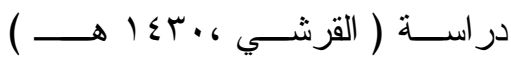

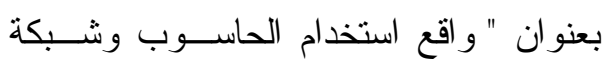


الذات هو المعلومات.حيــث ت تختلــــ

مصادر الإشــباع هــــه بـــاختلاف

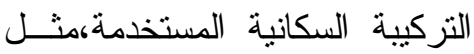

نوع الجنس،مسقط ر رأسه،وعمــره

$$
\text { المدرسي. }
$$

r- أثنار تحليل العلاقة بين احتياجــات

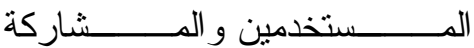

المدنيــــــة،ور الـــــسياسية إلـــــى أن

استخدامات المعلومات كانت أكثتر

ارتباطاً بالعمل المدني و الـسياسي

أكثر من الاستخدامات الترفيهية.

\section{الفصل الثالث: إجرائات الدراسة}

أولاً: منهج الدراسة

استخدم الباحث في هذه الدراســـة

$$
\text { المنهج الوصفي التحليلي }
$$

ثانياً: مجتمع وعينة الدر اسة

يتمنل مجتمع الدراســـة فـي جميـع

معلمي مو اد الدر اسات الإسـامية بالمرحلتين المتوسطة و الثانوية بمحافظة عفيف و البــالغ

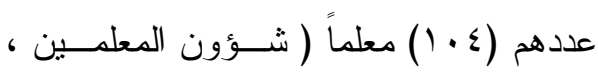

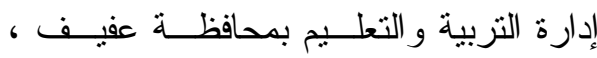

ع إ (هــ) ونظر ا لصغر مجتمع الدراســة

فقد استخدم الباحث أسلوب الحصر الـشامل وقد قام الباحث بتوزيع عدد (ع • ا) إســتبانة عاد منهم (Y (1) إستبانة وتم استبعاد عــدد (r) لعدم صـاحيتهم للتحليل وبالتالي أصـــح

\section{ـ - الدراسات الأجنبية:}

Pر اســة ) P.F., Nee, Kark,

2009 (Valenzuela,S) (بيئـة الـششبكة

الاجتماعيــة: مجمو عـــات الفــبس بــــوك،

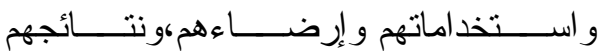

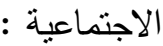

هدف الدر اسة: هدفت الدر اســـة إلــى

التعرف على مــدى إرضـــاء مجموعـــات

مستخذمي الفيس بوك، والعلاقة بين إرضاء

المستخدمين ومشاركتهم السياسية و المدنيــة

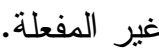

منهج الدر اسةة: اعتمــدت الدراســـة

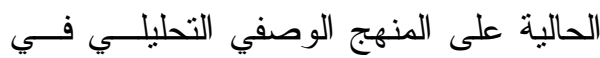
وصف الظاهرة موضوع الدراسة من خلال أدبيــــات الدر اســـــة (المؤلفــــات العلميـــــة، و الدر اسات السابقة)، إلـى جلى جــب تحليـلـل البيانات التي نم جمعها من و واقـع الدراســة

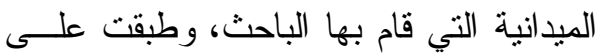

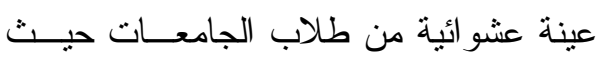

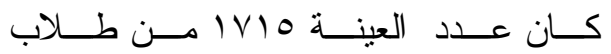
الجامعات.

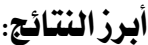

1. كثفت نتــائج الدر اســـة أن تحليــل

العامل عن أربعة احتياجات مبئية

للمشاركة في مجموعـات داخـلـل

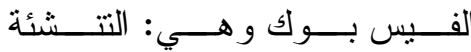

الاجتماعية،و الترفيه،و البحث عـن 
وفي ضو ء آر ائهم قام الباحث بإعداد أداة هذه الدارسة بصورتها النهائية. r - صدق الاتساق الداخلي:

بعد التأكد من الصدق الظاهري لأداة

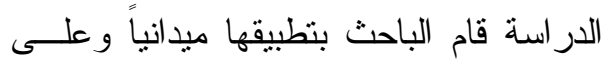

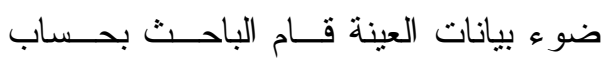

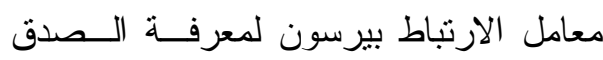

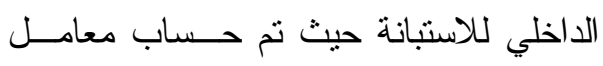

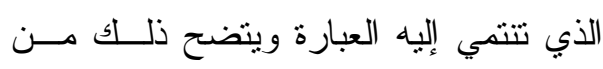

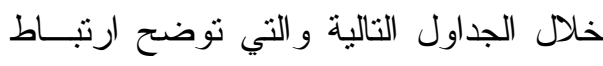
كل محور من المحاور مع عبار اته :

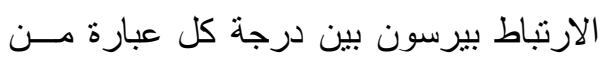

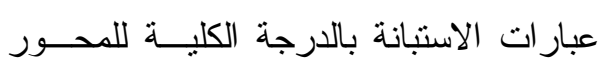

مجتمــع الار اســـة ( . . 1 ) معلمــاً لمـــو اد

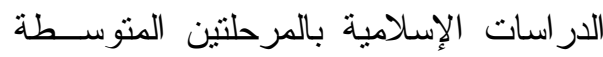
و الثانوية بمحافظة عفيف. ثالثاً: أداة الدراسة لتحقيق أهداف الدراسة و الإجابة على أسئلتها قام الباحث باستخدام أداة الاستبانة ولته الاجنه صدق أداة الدراسة وثباتها: قام الباحث بالتأكد مــن صــدق أداة

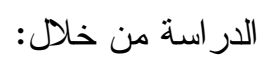
1- الصدق الظاهري: للتعرف على مدى صدق أداة الدر اسة في قياس ما وضعت لقياسه نم عرضها على مدي

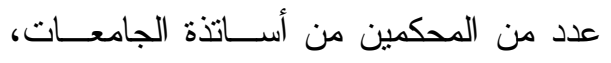

جدول رقم (1)

معاملات ارتباط بيرسون لعبارات المحور الأول (أوجه الاستفادة من خدمات الثبكة العنكبوتية

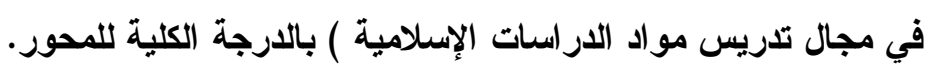

\begin{tabular}{|c|c|c|c|}
\hline معامل الارتباط بالمحور & رقم العبارة & معامل الارتباط بالمحور & رقم العبارة \\
\hline$* * 60 \leqslant$ & 11 & $* \% .010$ & 1 \\
\hline$* * .6709$ & Ir & $* * .70 Y$ & $r$ \\
\hline$* * 67 \leq \Lambda$ & $1 \pi$ & $* *$ * VOr & $r$ \\
\hline *\%. .0 r V & $1 \varepsilon$ & $* * 0 \leqslant V$ & $\varepsilon$ \\
\hline **..77 & 10 & $* * .711$ & 0 \\
\hline$* * .67 \leqslant V$ & 17 & $* * .0 \leq r$ & 7 \\
\hline 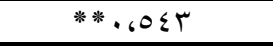 & IV & $\% * .0 \mathrm{~V}$ & V \\
\hline$* \% .6799$ & 11 & $* * 61 \mathrm{~T}$ & $\Lambda$ \\
\hline \multirow[t]{2}{*}{ ***. . TYY } & 19 & **. . TrY & 9 \\
\hline & & $* \%$. $0 Y 7$ & 1. \\
\hline
\end{tabular}

* دالة عند مستوى الدلالة ه .. . فأقل. ** دالة عند مستوى الدلالة ا ـ.، . فأقل. 
جدول رقم (ץ)

معاملات ارتباط بيرسون لعبارات المحور الثاني (الآليات التي يمكن أن تؤدي إلى زيادة

الاستفادة من خدمات الثبكة العنكبوتية في تدريس مواد الدراسات الإسلامية) بالارجة الكلية للمحور.

\begin{tabular}{|c|c|c|c|}
\hline معامل الارتباط بالمحور & رقم العبارة & معامل الارتباط بالمحور & رقم العبارة \\
\hline$* * \cdot .7 \leq \Lambda$ & 11 & $* .6701$ & 1 \\
\hline$* *$. เ V^ & ir & $* * .679 \%$ & $r$ \\
\hline$* * .69 r$ & 14 & $* * .6707$ & $r$ \\
\hline$* * 67 \mathrm{~V}$. & $1 \leq$ & $* * .645$ & $\varepsilon$ \\
\hline *.677 & 10 & $* *$. . O Y V & 0 \\
\hline$* * .67 \leq$. & 17 & $* * .67 V Y$ & 7 \\
\hline **. .7V V & iv & $* * .791$ & $\mathrm{~V}$ \\
\hline$* * .6701$ & 11 & $* * .64 \wedge \varepsilon$ & $\Lambda$ \\
\hline$* * .719$ & 19 & $* \% .679$ & 9 \\
\hline & & $* * .71$. & 1. \\
\hline
\end{tabular}

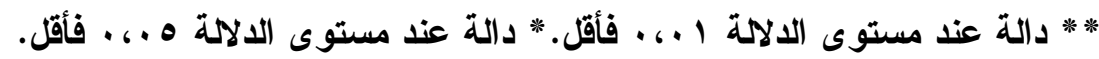

جدول رقم (r)

معاملات ارتباط بيرسون لعبارات المحور الثالث (المعوقات الثخصية والإدارية والتقتية التي قد تحول دون الاستفادة من خدمات الثبكة العنكبوتية في تدريس مواد الدراسات الإسلامية) بالارجة الكلية للمحور.

\begin{tabular}{|c|c|c|c|}
\hline معامل الارتباط بالمحور & رقم العبارة & معامل الارتباط بالمحور & رقم العبارة \\
\hline$* *, .7 \leq 0$ & $\Lambda$ & $* * .701$ & 1 \\
\hline$* \% .671 \mathrm{r}$ & 9 & $* * .67 \leq 9$ & $r$ \\
\hline$* .6701$ & 1. & $* * .07 \mathrm{~V}$ & $r$ \\
\hline *.74 & 11 & **. .7VI & $\varepsilon$ \\
\hline$* * 0 \wedge 1$ & ir & $* * \cdot 67 \leqslant \Lambda$ & 0 \\
\hline$* \% .6707$ & ir & $* \% .6700$ & 7 \\
\hline$* *, 0 \leq 4$ & $1 \leqslant$ & $* *, .0 \vee r$ & $\mathrm{~V}$ \\
\hline
\end{tabular}

** دالة عند مستوى الدلالة ا ..، . فأقل. الدراسة ،حيث طبقت المعادلة لقياس الصدق ثبات أداة الدراسة: البنائي و الجدول رقم (ع) يوضح معساملات

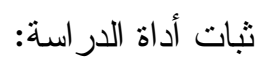
استخدم الباحث ( معادلة ألفا كرونباخ (Cronbach'a Alpha 


\section{جدول رقم (£)}

معامل ألفا كرونباخ لقياس ثبات أداة الدر اسة

\begin{tabular}{|c|c|c|c|}
\hline ثبات المحور & عدد العبارات & محاور الاستبانه & 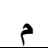 \\
\hline$\cdot, V T \leq$ & 19 & أوجه الاستفادة من خدمات الشبكة العنكبوتية في مجال تدريس مواد & 1 \\
\hline$\cdot, \vee \vee \wedge \top$ & 19 & 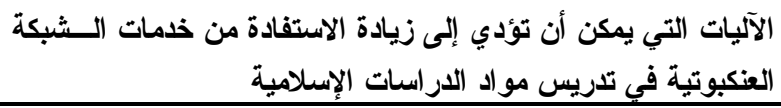 & r \\
\hline$\cdot, \wedge \cdot \wedge$ & $1 \varepsilon$ & المعوقات الشخصية والإدارية والتقنية التي قد تحول دون الاستفادة & $r$ \\
\hline$\cdot, \vee \vee \vee T$ & or & الثبات العام لمحاور الدر اسة & \\
\hline
\end{tabular}

r الانحر اف المعيـاري " Standard

رابعاً :أساليب المعالجة الإحصائية

. " Deviation

الفصل الرابع: عرض النتائج وتفسيرها وتحليلها

( ) الوسط الحسابي الموزون ( المرجح)

أولاً :عرض نتائج البيانات وتفـسيرها

. "Weighted Mean"

وتحليلها .

r المتوسط الحسابي " Mean " .

جدول رقم (0)

توزيع أفر اد الدراسة وفق متغير العمر

\begin{tabular}{|c|c|c|}
\hline النسبة & التكر ار & العمر \\
\hline$\%$ r. & $r$ r. & أقل من · س سنة \\
\hline$\%$ & 0. & من · r سنة إلى أقل من · ـ سنة \\
\hline$\% r$. & $r$. & من · ك سنة إلى أقل من · • سنة \\
\hline$\%$ & . & من · • سنة فأكثر \\
\hline$\% 1 \ldots$ & $1 \ldots$ & المجموع \\
\hline
\end{tabular}

جدول رقم (")

توزيع أفراد الاراسة وفق متغير عدد سنوات الخبرة

\begin{tabular}{|c|c|c|}
\hline النسبة & التكرار & عدد سنوات الخبرة \\
\hline$\% 1$. & 1. & أقل من • سنوات \\
\hline$\%$ YI & r) & من • سنوات الى أقل من ـ سنوات \\
\hline$\% r \leq$ & $r \varepsilon$ & من · 1 سنوات الي أقل من 1 سنة \\
\hline$\% \varepsilon$. & $\varepsilon$. & من 10 سنة الى أقل من · r سنة \\
\hline$\% 0$ & 0 & من · r سنة فأكثر \\
\hline$\% 1 \ldots$ & $1 \ldots$ & المجموع \\
\hline
\end{tabular}




\section{جدول رقم (v)}

توزيع أفراد الارسة وفق عدد الساعات اليومية التي تقضيها

\begin{tabular}{|c|c|c|}
\hline النسبة & التكر ار & عدد الساعات \\
\hline$\% 17$ & 17 & أقل من سـاعة \\
\hline$\% \leq r$ & $\leq r$ & من ساعة إلى أقل من ساعتين \\
\hline$\%$ ro & ro & من ساعتين إلى أقل من ثلاث ساعات \\
\hline$\% 10$ & 10 & من ثلاث ساعات فأكثر \\
\hline$\% \quad r$ & r & لا أستخدمه \\
\hline$\%, \ldots$ & $1 \ldots$ & المجموع \\
\hline
\end{tabular}

جدول رقم (^)

توزيع أفراد الاراسة وفق متغير عدد الدورات التدريبية

\begin{tabular}{|c|c|c|}
\hline النسبة & التكرار & عدد الاورات التدريبية \\
\hline$\% \wedge$ & $\Lambda$ & لا شيئ \\
\hline$\% 10$ & 10 & دورة و احدة \\
\hline$\%$ \%rr & rt & دورتان \\
\hline$\%$ ro & ro & ثلاث دور ات \\
\hline$\% 1 \leq$ & $1 \leqslant$ & أربع دور ات \\
\hline$\% \circ$ & 0 & أكثر من أربع دورات \\
\hline$\%, \ldots$ & $1 \ldots$ & المجموع \\
\hline
\end{tabular}

المحور الأول: أوجه الاستفادة من خدمــة

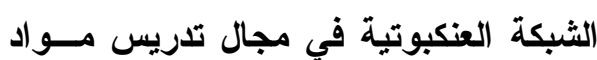

ثانيا : عـرض نتـائج أسـئلة الدراسـة و تفسيرهـا

الار اسات الإسلامية. 
جذول رقم (9) استجابات أفر اد العينة على عبارات أوجه الاستفادة من خدمة الثبكة العنكبوتية

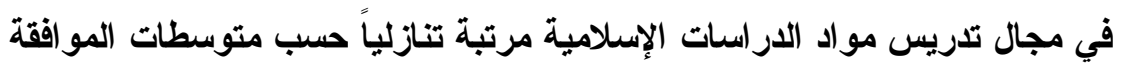

\begin{tabular}{|c|c|c|c|c|c|c|}
\hline المواققة & المعياري الإف & المئوية - النسبة & المتوسط & 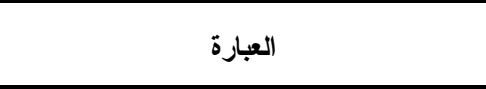 & \begin{tabular}{|l} 
العبارة في \\
\end{tabular} & الترتيب \\
\hline مو افق بشدة & $\cdot, 049$ & $\Lambda \wedge, r$ & $\{, \S$ & تعزيز التفاعل بين الطالب و المعلم & $r$ & 1 \\
\hline مو افق بشدة &., $07 r$ & $\Lambda \vee, \varepsilon$ & $\varepsilon, r V$ & تعزيز الثفاعل داخل الفصل & 1 & $r$ \\
\hline مو افق بشدة & $\cdot, 7 \vee \leq$ & Av & \& & بالمادتفادة من بعض الوسائل التعليمية المنصلة & 7 & $r$ \\
\hline مو افق بشدة & $\cdot, 7 \wedge 1$ & $\Lambda \uparrow, \Lambda$ & $\varepsilon, \Gamma \varepsilon$ & زيادة إمكانية الاتصال بين الطلبة فيما بينهم & $\Lambda$ & $\varepsilon$ \\
\hline مو افق بشدة & $\cdot, 01 \mathrm{~V}$ & $\Lambda ५, r$ & \&, & المختلفة اصل مع المعلمين من خلال زيارة المو اقع & Tr & 0 \\
\hline مو افق بشدة & . & $\Lambda \bullet, \Lambda$ & $\varepsilon, Y q$ & جذب الطلاب للتعلم & 17 & 7 \\
\hline مو افق بشدة & $\cdot, 7 \leqslant 0$ & $\wedge 0,4$ & $\varepsilon, Y \wedge$ & الوصول إلى المعلومة بكل سهولة & 11 & V \\
\hline مو افق بشدة & $\cdot, 701$ & 10 & $\varepsilon, r_{0}$ & زيادة دافعية الطلاب نحو التعلم & 9 & $\Lambda$ \\
\hline مو افق بشدة & $\cdot, 77$ & $\Lambda \varepsilon, 7$ & $\varepsilon, Y r$ & مساعدة الطلاب على التحصيل الدراسي & IV & 9 \\
\hline مو افق بشدة & $\cdot, 0$, & $\Lambda \varepsilon, r$ & $\varepsilon, r_{1}$ & تو مكان العملية التعليمية حيث لا ترتبط بزمسـان & 19 & 1. \\
\hline مو افق & $\cdot, T \leqslant Y$ & $\wedge r, \varepsilon$ & $\varepsilon, 1 V$ & الحصول على أساليب منتوعة & 1. & 11 \\
\hline 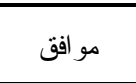 & $\cdot, T \leq T$ & $\Lambda r, \uparrow$ & $\varepsilon, 1 T$ & بالمادة الدر اسية المحتو يات التعليميـــة المتعلقـــة & it & IT \\
\hline مو افق & $\cdot$, OYV & $\wedge 1, \wedge$ & $\varepsilon, .9$ & تعزيز التفاعل بين البيت و المدرسة & $r$ & 14 \\
\hline 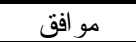 &., 071 & $\vee \vee, \wedge$ & $r, 99$ & رصد نتائج الطلاب في الموقع المخصص لذلك & 10 & $1 \varepsilon$ \\
\hline 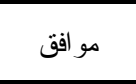 & ו ו & VV & ऍ,^० & 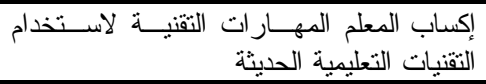 & $\varepsilon$ & 10 \\
\hline 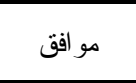 & • & V५, r & $r, \wedge 1$ & الطلاب على التحرف البرامج التعليمية التــي تـسـاعد & 11 & 17 \\
\hline 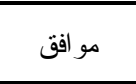 & $\cdot, 0 \leqslant 1$ & vo & r,vo & 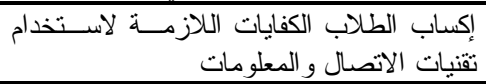 & 0 & IV \\
\hline 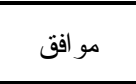 & $\cdot, T \vee V$ & $V \varepsilon, r$ & $r, v_{1}$ & تققيم أنشطة تعليمية تعزز التعاون بين المعلمين & V & 11 \\
\hline 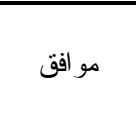 & $\cdot, T Y V$ & Vr & ק & 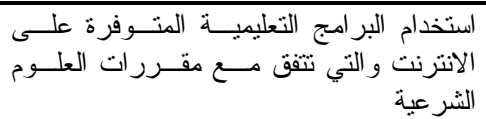 & $1 \leqslant$ & 19 \\
\hline \multicolumn{3}{|c|}{ مو افق } & $\varepsilon, 11$ & المتوسط العام & & \\
\hline
\end{tabular}

متوسط يقع في الفئة الر ابعة و الذي يشير إلى

يتبــين مسـن الجــدول رقـــم (9) أن

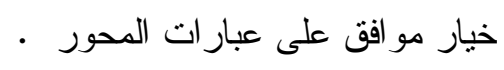

المتوسط العام لاستجابات أفر اد عينة الدر اسة دولة

المحور الثاني: الآليات التي يمكن أن تؤدي

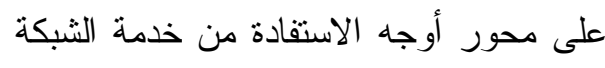
إلى زيادة الاستفادة من خــدمات السشبكة العنكبوتية في مجال تدريس مو اد الدر اســات

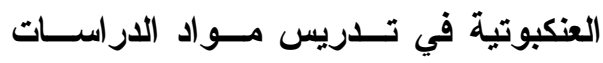

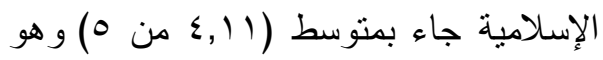
الإسلامية . 
جدول رقم ( • 1) يوضح استجابات أفراد الدراسة على عبارات محور : الآليات التي يمكن أن تؤدي إلى زيادة الاستفادة من خدمات الثبكة العنكبوتية في تدريس مواد الدراسات الإسلامية

من وجهة نظر أفراد عينة الدراسة

\begin{tabular}{|c|c|c|c|c|c|c|}
\hline الموجة & الإمعياري & المئوية - النسية & المتوسطي & 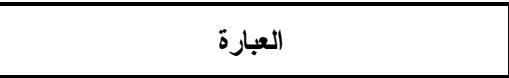 & العبارة في & الترتيب \\
\hline مو افق بشدة & $\cdot, T Y V$ & $\wedge 9,7$ & $\varepsilon, \S \wedge$ & 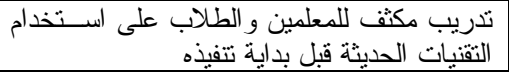 & 10 & 1 \\
\hline مو افق بشدة & • & $\wedge \wedge, \varepsilon$ & $\varepsilon, \varepsilon Y$ & في الفصل بيئة تعليمبة تعلميه تفاعلية بطريقة متز امنة & 1 . & r \\
\hline مو افق بشدة & $\cdot, 711$ & $\Lambda \mathrm{V}, \Lambda$ & $\varepsilon, r q$ & تلثريب المعلمين بهدف الإلمام بمهار ات استخدام & 19 & r \\
\hline مو افق بشدة &., $70 \leqslant$ & $\Lambda T, 7$ & $\varepsilon, \Gamma r$ & استخدام الإنترنت في التعليم & Y & $\varepsilon$ \\
\hline مو افق بشدة & $\cdot, T \leq Y$ & $10, \Lambda$ & $\varepsilon, \varphi^{\prime}$ & 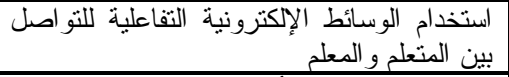 & 11 & 0 \\
\hline مو افق بشدة & $\cdot, 7 \cdot 1$ & $10, \varepsilon$ & $\varepsilon, Y V$ & أنتشاء بنالإنترنتية تحتية من أجهزة ومعامـلـل وخطـــوط & $1 \varepsilon$ & 1 \\
\hline مو افق بشدة & $\cdot, 791$ & $\wedge \varepsilon, \wedge$ & $\varepsilon, Y \varepsilon$ & 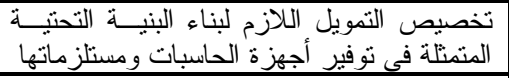 & 11 & $\mathrm{v}$ \\
\hline مو افق بشدة & $\cdot, 7 Y_{0}$ & $\Lambda \varepsilon, 7$ & $\varepsilon, Y T$ & تنتجيع استخدام الحاسوب داخل الفصل & 1 & $\Lambda$ \\
\hline 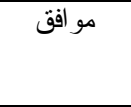 & $\cdot, T V \pi$ & $\Lambda \Gamma, \Lambda$ & $\varepsilon, 19$ & 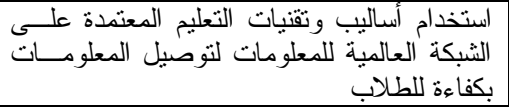 & $\wedge$ & 9 \\
\hline مو افق & $\cdot, 094$ & Ar, $\varepsilon$ & $\varepsilon, 1 V$ & جذادل زالتو اصل معروفة الطلاب و المعلمـين حسبـ & 0 & 1. \\
\hline مو افق & $\cdot, 70 \leq$ & $\Lambda, \Lambda$ & $\varepsilon, .9$ & 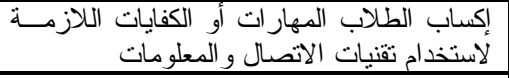 & ir & 11 \\
\hline مو افق & $\cdot, 749$ & $\lambda \cdot, r$ & $\varepsilon, \cdot 1$ & 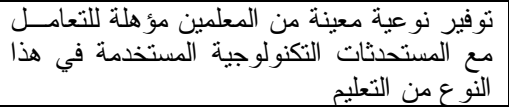 & 17 & ir \\
\hline مو افق &., 001 & $\mathrm{Vq}$ & $r, 90$ & توفير البر امج التعليمية باللغة العربية & IV & 14 \\
\hline مو افق & $\cdot, 0 \leqslant r$ & $V V, T$ & $r, \wedge \Lambda$ & 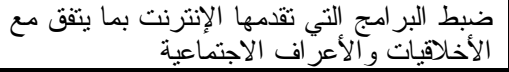 & 1 & $1 \varepsilon$ \\
\hline مو افق ل & $\cdot, T \vee \wedge$ & $V 7, r$ & $r, \Lambda)$ & استخدام نظام مجموعات الأخبار في التعليم & r & 10 \\
\hline 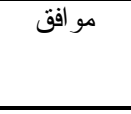 & $\cdot, 7 \wedge \varepsilon$ & $V \varepsilon, Y$ & $r, v$ & 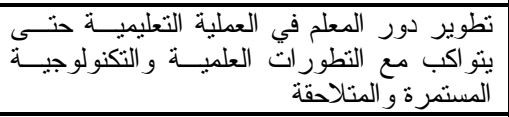 & 14 & 17 \\
\hline مو افق &., $01 \leqslant$ & $\mathrm{VT}$ & $r, 70$ & استخدامات بر امج المحادثة في التعليم & $\varepsilon$ & IV \\
\hline مو افق & $\cdot, 79 \mathrm{~V}$ & $\mathrm{~V}, 1,1$ & $r, 09$ & استخدام الكتاب الإلكترونى & v & 11 \\
\hline مو افق & $\cdot, 7 \times 1$ & $\sqrt{11}$ & $r, 00$ & التو اصل بين المعلمين حول المو اد الدر اسية و التعليج & 9 & 19 \\
\hline \multicolumn{3}{|c|}{ مو افقي } & $\varepsilon,+7$ & \multicolumn{3}{|l|}{ المتوسط العام } \\
\hline
\end{tabular}

محور الآليات التي يمكن أن تؤدي إلى زيادة

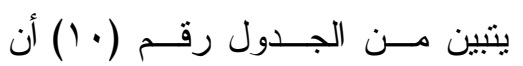

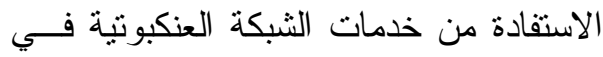

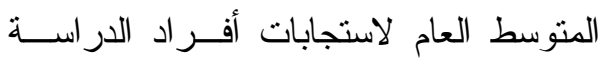

تدريس مواد الدر اســات الإســلامية جــاء

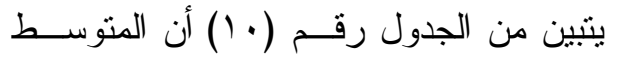

بمتوسط (T +, ع من 0) وهو منوسط يقع في

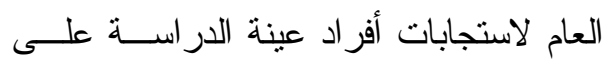


الفئة الر ابعة و الذي يثير إلى خيار موافـق المحـور الثالــث : المعوقـــات الثخــصية

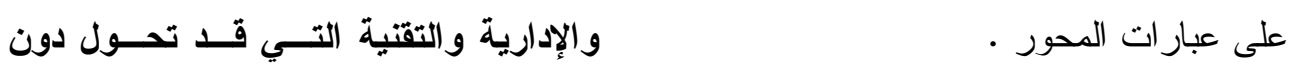
الاستفادة من خدمات الشبكة العنكبوتية في والاديه

تدريس مواد الاراسات الإسلامية

جدول رقم (1 1) استجابات مفردات الدراسة على عبارات محور المعوقات الثخصية والإدارية و التقنية التي قد تحول دون الاستفادة من خدمات الثبكة العنكبوتية في تدريس مواد الدراسات الإسلامية مرتبة تنازلياً حسب متوسطات الموات الفقة

\begin{tabular}{|c|c|c|c|c|c|c|}
\hline الموجة & 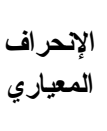 & المئوية & | المستوسط & 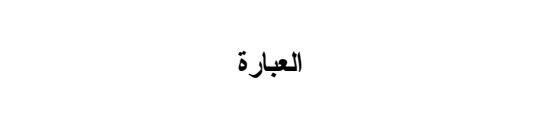 & العبارة & الترتيب \\
\hline 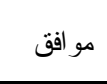 & $\cdot, 0 Y \wedge$ & Ar, r & $\varepsilon, 17$ & 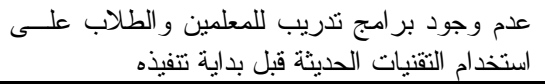 & V & 1 \\
\hline مو افق & $\cdot, 717$ & $\wedge 1,7$ & $\varepsilon, . \wedge$ & عدم إلمام المدرسين باستخدام الانترنت & 9 & $r$ \\
\hline 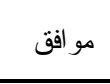 & $\cdot, T V \cdot$ & $\wedge \cdot, \Sigma$ & $\varepsilon, \cdot r$ & 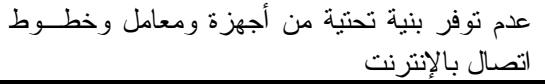 & 11 & r \\
\hline 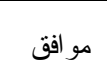 & $\cdot, 009$ & $\vee १, \wedge$ & $r, 99$ & الإكتروني وجود متخصصين في الإدارة بأنظمة التعلــيم & ir & $\varepsilon$ \\
\hline 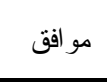 & $\cdot, 0 \vee \wedge$ & $V Y, r$ & $r, \wedge \uparrow$ & 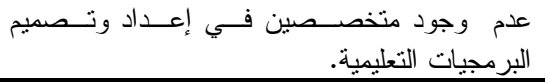 & $\varepsilon$ & 0 \\
\hline 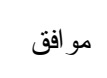 & 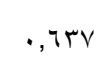 & $V ฯ, r$ & $r, \wedge 1$ & عدم إلمام المتعلمين بمهــــار ات اســتخدام التقنتـــات & 1 & 7 \\
\hline 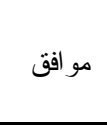 & $\cdot, 7 r q$ & $v_{0}, \varepsilon$ & $r, v V$ & تكاليف توفر أجزة الحاسوب، تكاليف تصمية اللازمة لتطبيقه منل & 0 & v \\
\hline 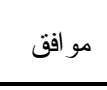 & $\cdot, 7 \cdot V$ & $V \varepsilon, r$ & $r, v_{1}$ & و وتقضيلهم الطريقة النقليدية في إعطاء الاعتماد على التقبات الحديثة & r & $\wedge$ \\
\hline 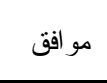 & $\cdot, 701$ & $v r, r$ & $r, 77$ & عدو اد الاقتتاع بأهمية استخدام الانترنت في تـدريس & $\wedge$ & 9 \\
\hline 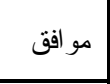 & $\cdot, 7 \wedge 1$ & vr & r, & 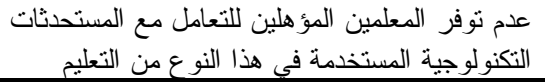 & $r$ & 1. \\
\hline 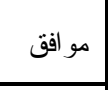 & $\cdot, 0 r \leq$ & $V Y, r$ & $r, 71$ & المعلم و الطلاب التو اجد الإنساني و العلاقات الإنسانية بين & 7 & 11 \\
\hline 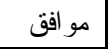 & •,OMr & $\vee, \wedge$ & $r, 09$ & عدم تشجيع الددرسين على استخدام الانترنت & 1. & ir \\
\hline 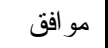 & $\cdot, 0 \leqslant r$ & $v_{1}, \varepsilon$ & $r, \diamond V$ & عدم جودة سرعة الاتصـال أثثاء الاستخدام & $1 \varepsilon$ & ir \\
\hline 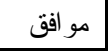 & $\cdot, T \leqslant V$ & $V \cdot, r$ & $r, 01$ & عدم توفر البر امج التعليمية باللغة العربية & ir & $1 \leqslant$ \\
\hline & & 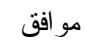 & $r, v \wedge$ & \multicolumn{3}{|l|}{ المتوسط العام } \\
\hline
\end{tabular}


- جاء المتوسط العام لاستجابات أفـــراد

الدر اسة بمتوسط يــثير إلــى خيــار

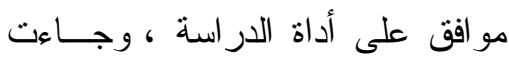

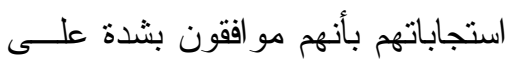

$$
\text { عدد (^) عبار ات . }
$$

- وجاءت استجاباتهم بأنهم مو افقون على

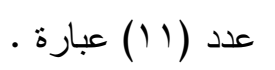

المحسـور الثالــث : المعوقــات الثخــصية

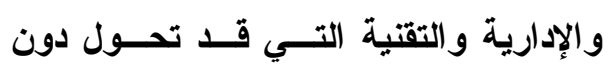
الاستفادة من خدمات الثبكة العنكبوتية في تدريس مواد الاراسات الإسلامية - جاء المتوسط العام لاستجابات أفـــــر اد عينة الدر اسة بمتوسط يثبر إلى خيار

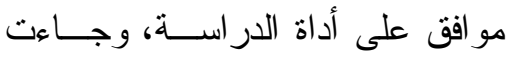

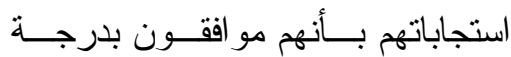
مو افق على عدد (ع ا ) عبارة . * توصيات الدراسة :

من خلال النتائج التي تم التوصــل إلبها فإن الباحث يوصي بالآتي :

- العمل على إعـــداد بــــر امج تدريبيـــة

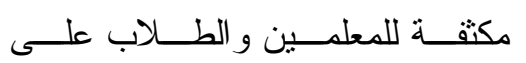
استخدام الانترنت في التعليم و الــتعلم

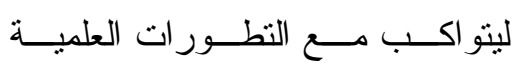
و التكنولوجية المستمرة .
يتبين مسن الجـدول رقــم (1) أن المتوسط العام لاستجابات أفر اد عينة الدر اسة ردة على محور المعوقات الثخصية و الإداريـــة و التقنية التي قد تحول دون الاســتفادة مــن خدمات الثبكة العنكبوتية في تدريس مــواد

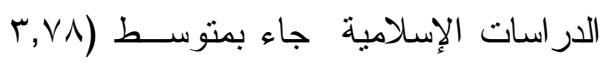
من 0) و هو متوسط يقع في الفئــة الر ابعـــة و الذي يشير إلى خيار مو افق على عبـــار ات

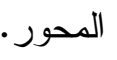

\section{ثالثاً : ملخص نتائج الدراسة.}

جاعت ابــرز النتــائج المتعلقــة بمحسـاور الار اسة:

المحور الأول: أوجه الاستفادة من خدمــة الثبكة العنكبوتية في مجال تدريس مــواد الد الاوله الار اسات الإسلامية - جاء المتوسط العام لاستجابات أفـــر اد عينة الدر اسة بمنوسط يثير إلى خيار

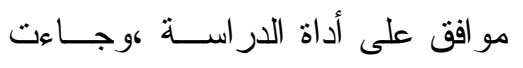

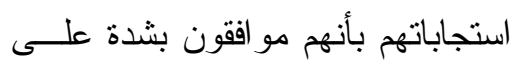

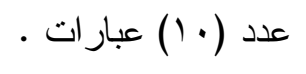
- جاءت استجاباتهم بأنهم موافقون على ألى

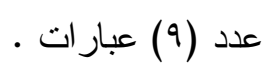

المحور الثاني: الآليات التي يمكن أن تؤدي

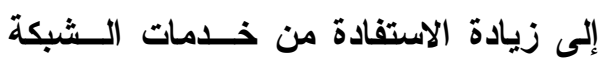

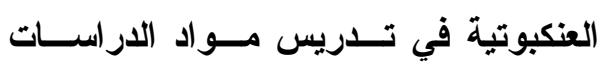
الإسلامية : 


$$
\begin{aligned}
& \text { - العمل على الاستفادة مــن التقنيـات المراجع } \\
& \text { الموجودة بأغلب المدارس وتوفير مال المراجع العربية: }
\end{aligned}
$$

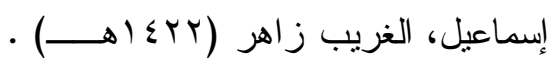

$$
\begin{aligned}
& \text { ينقص البقية . } \\
& \text { تكنولوجيا المعلومات وتعديث التعلــيم. }
\end{aligned}
$$

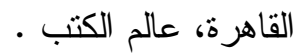

$$
\begin{aligned}
& \text { بر هان، محمد نور ( } 1999 \text { ) ـ تقنيــة } \\
& \text { المعلومــات وتحـــيات الإدارة العامــة } \\
& \text { العربية في عقد التـسعينات ـ المجلــة } \\
& \text { العربية للإدارة، الصادرة عن المنظمــة } \\
& \text { العربية للتنمية الإدارية، مج لـ } 19 \text { ـ } 19 \\
& \text { تجار الـشاهي، أروى بنــت إبــماعيل } \\
& \text { a) }
\end{aligned}
$$

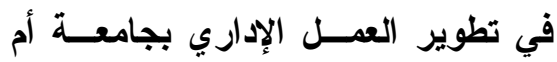

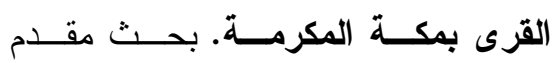

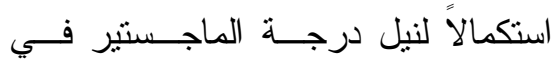

$$
\begin{aligned}
& \text { الإدارة التزبية و التخطيط، قـسم الإدارة }
\end{aligned}
$$

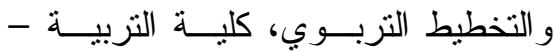

$$
\begin{aligned}
& \text { جامعة أم القرى، مكة المكرمة. }
\end{aligned}
$$

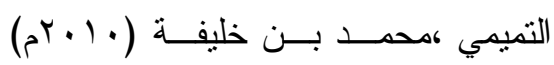

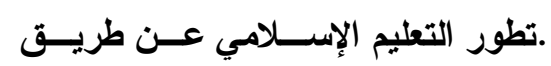

$$
\begin{aligned}
& \text { الإتترنت، وتجربة جامعة المدينة العالمية }
\end{aligned}
$$

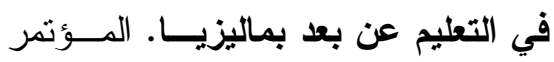

$$
\begin{aligned}
& \text { الدولى حول دور الدر اسات الإسلامية في بعائي } \\
& \text { المجتمع العولمي ، الب-r د ديسمبر • } \\
& \text { التودري، عـوض حسـين ( ع ... ب ). } \\
& \text { تربويات الكمبيوتز :المدرسة الإكترونية } \\
& \text { - إقامة ورش عمل بهدف رفع مستوى }
\end{aligned}
$$

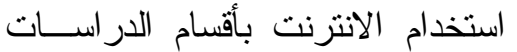

$$
\begin{aligned}
& \text { الإسلامية لزيــادة وعـي المعلمـين } \\
& \text { بأهية استخدام الانترنت . } \\
& \text { - العمل على تفعيل اســتخدام أســاليب } \\
& \text { وتقنيات التعليم المعتمدة على الــشبكة }
\end{aligned}
$$

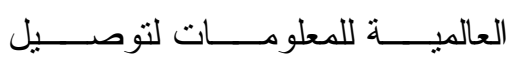

$$
\begin{aligned}
& \text { المعلومات بكفاءة للطلاب. } \\
& \text { - العمل علـى رفــع مـسنتوى اللغـــة }
\end{aligned}
$$

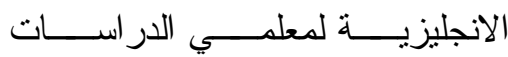

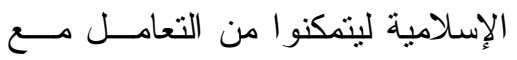

$$
\begin{aligned}
& \text { أجهزة الحاسب بكفاءة عالية . } \\
& \text { - إدر اج استخدام الانترنت في التنريس } \\
& \text { من ضمن بنود تقييم الأداء الـــوظيفي } \\
& \text { - للمعلم } \\
& \text { * مقترحات الدراسة : } \\
& \text { / / إجر اء در اسة حول و اقــع اســتخدام } \\
& \text { الثبكة العنكبونية في تــدريس مـــواد } \\
& \text { الدر اســات الإســـامية بــــالمرحلتين } \\
& \text { المتوسطة و الثانوية ( بنات ) ) } \\
& \text { / إجر اء دراسات ممانتلة لبقية المــواد }
\end{aligned}
$$

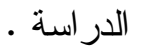




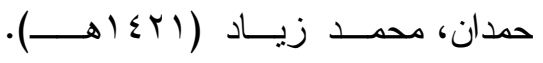

تكنولوجيا التعلم والتــدريس والتربيــة الإكترونية عن بعد. الأردن، دار التربية الحديثة . الإنية الدباسي، أريج صالح ( استخدام برمجيات الحاسب الآلــي فــي تدريس اللغة الإنجليزية على تحـصيل تلميذات الصف السادس الابتائي بمدينة

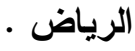
الدركزلي، شذى ( 1997 ( ). الإنترنــــ ثروة المعلومات والثقافة والتعليم .مجلة آفاق الثقافة . رانثد، علي (ب991م). مفاهيم ومبادئ تربوية، القاهرة، دار الفكر العربي .

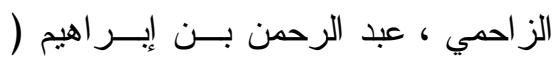

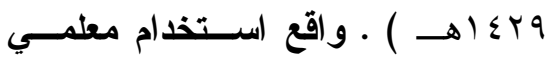
الفيزياء بالمرحلة الثانوية في محافظــة القنفذة لشبكة الانترنت في التدريس من فئن وجهة نظرهم · رسالة ماجستير ( غيــر

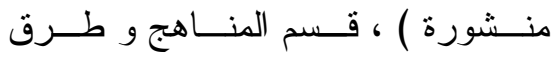
التدريس ، كلية التربية ، جامعة أم القرى ، مكة المكرمة.

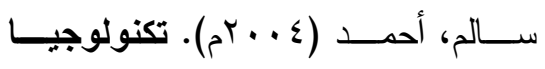
التعليم والتعليم الإكتروني، مكتبة الرشد

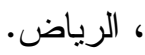

و أدوار حديثة للمعلم .الرياض، مكتبـــة

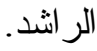

الجمال، راسم محمد (1999 ) ـ مناهج

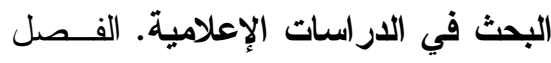

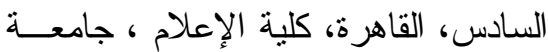

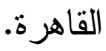

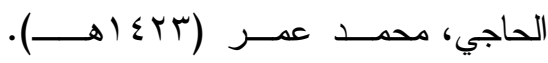
الإنترنـــت : إيجابياتــهـه وســلبياته. دار

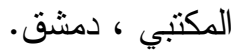
الحجي ، نهلة بنت عبد الله (•r؟ اهـ ) • مدى استخدام الاتترنت في التـــريس بأقسام الدراسات الإســلامية بكليـات

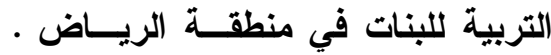
رسالة ماجسنتير ( غير منشورة ) ، قسم المناهج و طرق التثريس ، كلية التزبية ، جامعة الملك سعود ، الرياض .

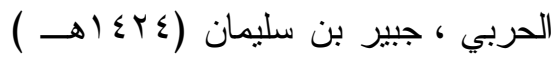

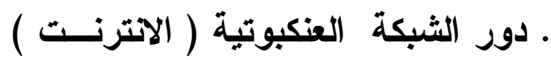
في تدريس العلــوم الــشرعية بكليــات المعلمين وسبل تطــوير اســتخدامها . رسالة ماجستير ( غير منشورة) ، قـسم لطمئ المناهج و طرق التنريس ، كلية التربية ، جامعة أم القرى ، مكة المكرمة .

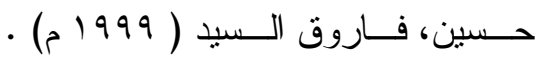
الانترنت شبكة المعلومسـات العالميــة. القاهرة، هلا للنشر و التوزيع. 
المعلمين والمشرفين التربويين • رسالة

مقدمة استكمالا لمنطلبات الحصول على ولى

درجة ماجستير الآداب في طرق تدريس لإنس

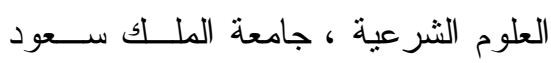

كلية التربية قسم المناهج وطرق التنريس

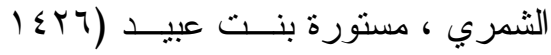

هـ) ـ الاحتياجات التدريبية في الحاسب

والانترنت لمعلمات العلــوم الــشرعية بالمرحلة المتوسطة في محافظة حفـر

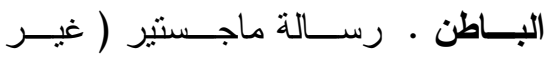
منشورة) ، قسم التربية ، كليــة العلـــوم

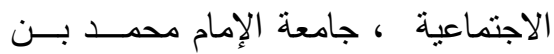
سعود الإسلامية ، الرياض .

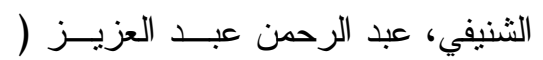

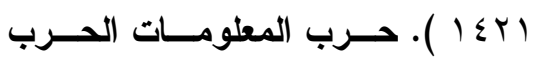
القادمة :الاليل الشامل لحرب المعلومات .

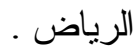

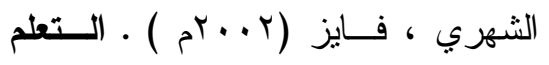
الإكتروني في المـــارس الـسعودية .

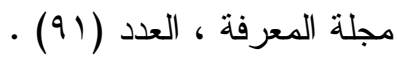

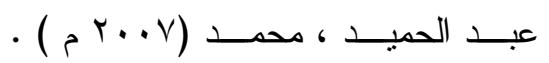

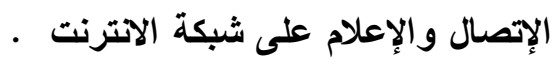
القاهرة ، عالم الكتب .

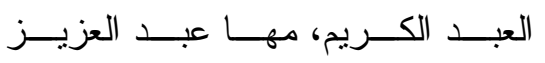

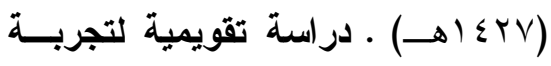

سمبسون ، ألان ( 1999 م ) ـ الانترنت

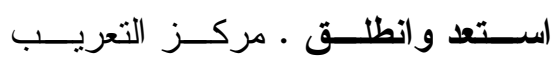

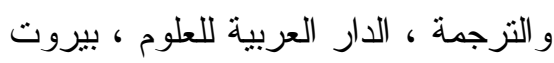
السنابل، محمد إبــر اهيم ( . . ب م م ) . الانترنت. ط ז، مكتبة لبنان، بيروت.

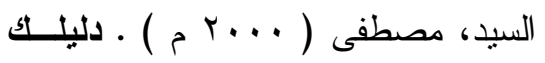
الثامل إلى شبكة الاتترنت ـ ط ب م، دار الكتب العلمية للنشر و التوزيع، القاهرة. الثريف، موضي بنت نايف بن جعفــر

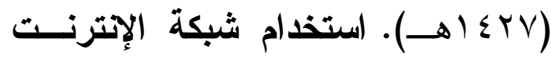
وعلاقته بالـــافع المعرفــي والميـــول

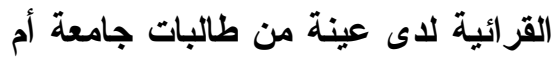
القرى بمدينة مكة المكرمة. بحث مقــدم

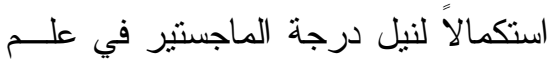
النفس تخصص علم نفس تربوي، قـسم التربية و علم النفس كلية التربية للبنــات،

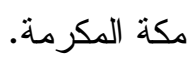
الشماع، محمد (11 (1) ) ـ أيام الحرية في ميدان التحرير، ثمانية عثر يومـاً

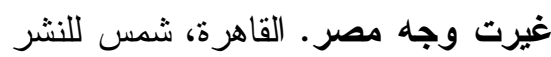

$$
\text { و التوزيع عيزت }
$$

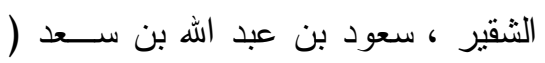

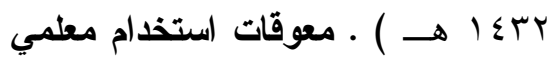
العلوم الثرعية مركز مــصادر الــتعلم

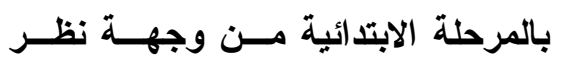


العمري ، محمد خليفة. (r . .rم) • واقع

استخدام الإنترنت لاى أعـضـاء هيئــة

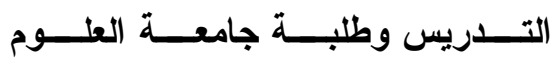

و التكنولوجيا الأردنية ـ الأمانة العامــة

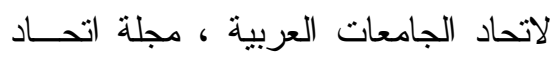

الجامعات العربية ، العدد (• ع).

الغامدي ، عبد اله أحمد بــن علـي آل

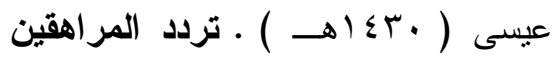
على مقاهي الاتترنت وعلاقتّه بــبعض

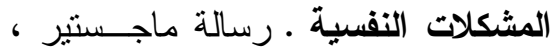

جامعة أم القرى ، كلية التربيــة ، مكـــة

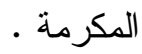

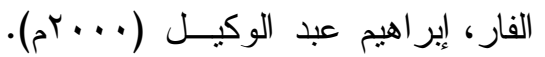

التكنولوجيا وتطوير التعليم.دار غريب

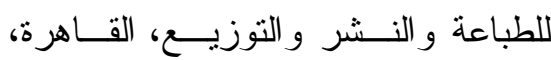

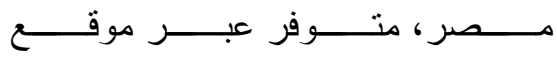
inttp://www.31lm.com

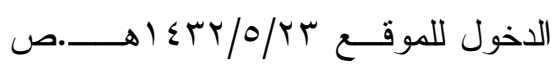

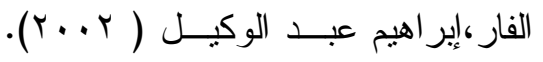
استخدام الحاسوب في التعليم. دار الفكر للطباعة و النشر و التوزيع، عمان، الأردن. القرشي ، وائل بن سالم (•rع اهـ) .

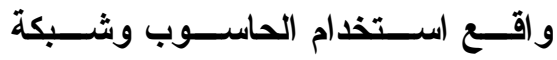
المعلومات الدولية الاتترنت في تدريس الرياضيات للصف الأول المتوسط فــي لالترني

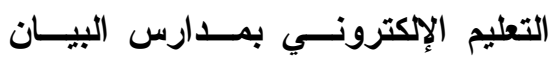

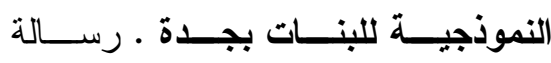

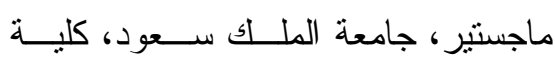

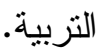

العبد القادر، عبد الله، و العنقري، خالـــــ حمد ( 1990 ). معوقات استيعاب تقتية المعلومات في القطاع الحكومي السعودي در اسة ميدانية .جامعة الملك فهد للبنرول

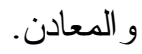

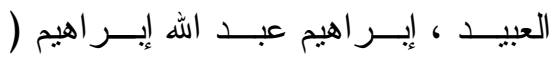

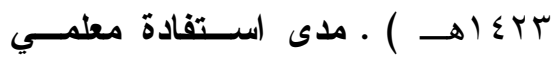

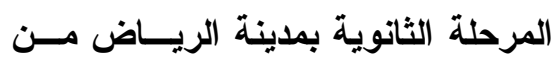
الشبكة العالمية للمعلومات " الانترنت ". رسالة ماجستير ( غير منشورة ) ، قسم وسائل وتكنولوجيا التعليم، كلية التربية ، جامعة الملك سعود ، الرياض . عليان، ربحي، وعبدالدبس( 1991 ام )

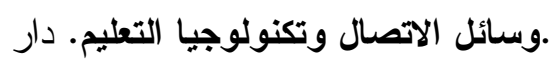
الصفا للنشر و التوزيع، عمان. عمر ، فدوى فاروق( ب . . r م). استخدام شبكة الاتترنت في إدارة مؤسسات التعليم العالي بالمملكة العربية السعودية. رسالة

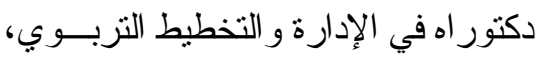

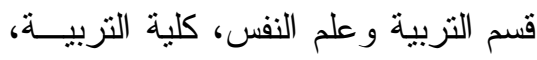
جدة. 
الإنترنت ـ المجلة التربويــة، جامعــة

الكويت، العدد . OV.

المر اجع الأجنبية :

Park, N.a , Kee, K.F.b , Valenzuela, S.c(2009) Being immersed in social networking environment: Facebook groups, uses and ratifications, and social outcomes Cyber psychology and Behavior, 12 (6), pp. 729-733.

Madge, C. ${ }^{\mathrm{a}}$, Meek, J. ${ }^{\mathrm{b}}$, Wellens, J. $^{\mathrm{c}}$, Hooley, T. ${ }^{\mathrm{d}}$ (2009)Face book, social integration and informal learning at university: 'It is more for socialising and talking to friends about work than for actually doing work' (2009) Learning, Media and Technology, 34 (2), pp. 141-155.

Tripathi, K. (1998), "The Internet and its Used in Education"، Retrieved December 11， 2004 from: http:// www.iteachnet.org/mar98/arunakumartripathimar98.html..

Czech, B.J.(2001) Beginning Teachers use of the Internet for classroom learning Activities: A study of affect, dissertation university of southern California, Digital dissertation.

$$
\begin{aligned}
& \text { محافظة الطائف ـ رسالة ماجستير ( غير } \\
& \text { منشورة ) ، قسم المناهج و طرق تدريس }
\end{aligned}
$$

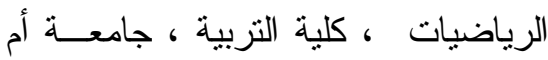

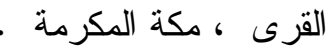

مجلة المعرفة. (ثــهر جمــاد الاخــرة، .

مصطفى ، الزيــات ، عبــــ القــادر ،

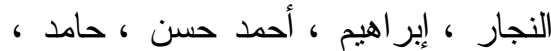

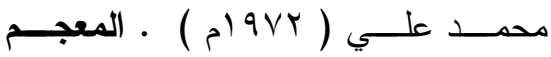

الوسيط ـ المجمع اللغوي بالقاهرة ، جr.

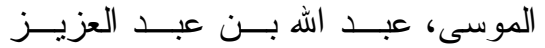

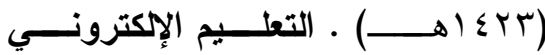

مفهومه، خصائصه، فو ائده، عوائقــه .

ورقة عمل مقدمة إلـى نــدوة مدرســـة

المستقبل، جامعة الملك سعود، الرياض.

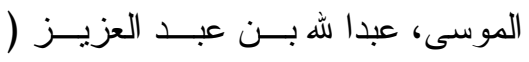

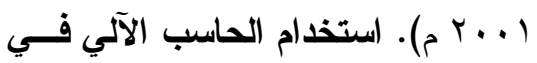

التعليم .مكتبة الثقري ، الرياض.

الموسوي، محمد جاسم فلحي(7 + . بم) .

اتجاهات إعلامية معاصرة ـ منـشور ات

الأكاديمية العربية المفتوحة الدانمرك .

الهابس، عبــــ الله صــالح ( . . . rم) .

الأسس العلمية لتصميم وحدة تعليمي عبر 